\title{
ALEGORÍAS CINEMATOGRÁFICAS DE LA CONQUISTA DE AMÉRICA. DEL APOCALIPSIS DE LOS IMPERIOS PRECOLOMBINOS AL ALBA DEL COLONIALISMO IMPERIAL
}

\author{
FILMIC ALLEGORIES OF THE CONQUEST OF AMERICA. \\ FROM PRE-COLUMBIAN APOCALYPSE TO THE DAWN OF \\ COLONIALIST IMPERIALISM
}

Víctor IturRegui-MOtIloAa \& Ignacio Gaztaka-EguskizaB

El análisis fílmico de las películas Retorno a Aztlán, Apocalypto, Alba de América y 1492. La conquista del paraíso servirá para identificar distintas maneras de representar la conquista de América desde diversas perspectivas a cada orilla del Atlántico. Nos centraremos en los temas, las estructuras narrativas y las expresiones formales que plantean estas cuatro obras. Así, las primeras conforman la mirada meso- y norteamericana y las dos últimas, el punto de vista español-europeo. Esta investigación concluye que en ambos continentes se utiliza el contexto cultural de Mesoamérica precolonial y poscolonial para moldear discursos político-ideológicos más cercanos a su propia realidad contemporánea que al pasado que recrean ficcionalmente.

Palabras clave: análisis cinematográfico, estudios hispánicos, estudios mesoamericanos, conquista de América, cine histórico, alegoría.

In this article, the film analyses of Retorno a Aztlán, Apocalypto, Alba de América, and 1492. Conquest of Paradise will be used to identify several ways in which the conquest of America is represented from a variety of perspectives on both Atlantic coasts. The study focuses on the themes, narrative structures, and formal expressions used in these four films. Thus, the first two films present the Mesoamerican and North American point of view, while the other two represent the Hispanic-European perspective. It is concluded that in both continents the cultural contexts of precolonial and postcolonial Mesoamerica are used in these films to shape ideological discourses, which are more related to their contemporary reality rather than to the past times they depict.

Keywords: film analysis, Hispanic studies, Mesoamerican studies, conquest of America, historical film, allegory.

\section{INTRODUCCIÓN}

El objetivo de la investigación es analizar cuatro formas de representación cinematográfica de un mismo acontecimiento primordial de la cultura hispánica y mesoamericana: la llegada de Cristóbal Colón a América en 1492. En concreto, las obras seleccionadas son Retorno a Aztlán (Mora Catlett 1990), Apocalypto (Gibson 2006), Alba de América (Orduña 1951) y 1492. La conquista del paraíso (Scott 1992). Se intenta demostrar que las imágenes que ilustran el descubrimiento y la conquista del llamado "Nuevo Mundo" y la forma en que se narran ejecutan un movimiento retórico-político desde ideologías claras y diversas por parte de las naciones involucradas en las efemérides. Analizaremos esta selección de relatos que emplean la potencia historicista del cine en relación con los cometidos políticos de la época en la que se produjeron. Esto permite catalogarlos como cine político, aunque a simple vista (por su aspecto iconográfico) no se enmarquen fácilmente en esta etiqueta. Estas cuatro obras demuestran que lo político del cine es perceptible en el contenido y en la expresión.

El cine despliega representaciones políticas fundadas en relatos provenientes de imaginarios, tradiciones y mitos. Como mecanismo masivo generador de signi-

A Víctor Iturregui-Motiloa, Universidad del País Vasco/Euskal Herriko Unibertsitatea, Bilbao, España. ORCiD: 0000-0002-8443-0790. E-mail: alloturturro11@gmail.com

B Ignacio Gaztaka-Eguskiza, Universidad del País Vasco/Euskal Herriko Unibertsitatea, Bilbao, España. ORCID: 0000-0001-9111-7316. E-mail: gatazka93@gmail.com

Recibido: agosto 2020. Aceptado: agosto 2021. 
ficados, se considera un medio de comunicación más que apropiado para moldear un discurso ideológico o político al gusto del emisor (y del espectador). Tal como señala Huguet (2002: 10), "la historia no puede entenderse sin esta memoria común edificada sobre imágenes, ficción, fábulas o mitos". En suma, "el paso del tiempo modifica la visión o lectura de una película de género histórico" (Huguet 2002: 19), por eso cuesta comprender las huellas del contexto anacrónicamente. De modo que solo desde el presente, y dando cuenta de la construcción fílmica, se puede extraer ese sentido político que se esconde en estas narraciones de aventuras coloniales. El arte cinematográfico es, en definitiva, una herramienta política capaz de forjar simbólicamente pensamientos muy arraigados y de transmitir ideas de un modo comunicativamente eficaz para los miembros de una comunidad concreta (espectadores). Este texto no busca hacer ningún tipo de valoración histórico-ética de los acontecimientos en cuestión. Más bien se centra en señalar las ideologías presentes en las distintas narraciones convocadas, identificando qué temas tratan, qué estructuras emplean y qué propuestas estilísticas exponen.

Para desgajar esos contenidos hemos realizado un análisis fílmico-narratológico. Como señala Zunzunegui (2016: 178), el análisis de la escena cinematográfica permite interpretar cómo "un principio temático se transforma en un principio formal". Por su parte, Casetti y Di Chio (1991: 25) caracterizan el análisis del filme como el desarrollo de una "hipótesis explorativa", que, en nuestro caso, rastrea los significados ya señalados entre los significantes cinematográficos. Aquí trataremos de hallar los mecanismos cinematográficos que dan forma audiovisual a las ideologías que se ocultan en cada una de las narraciones escogidas. Por tanto, abordaremos el análisis formal apuntando hacia el núcleo político que queremos extraer: del lenguaje cinematográfico al ideario político; del contexto presente a los hechos históricos pasados que se pretenden recrear.

\section{HISTORIA, NARRACIÓN, POLÍTICA (MARCO TEÓRICO)}

La representación ficcional de "acontecimientos" y "hechos" históricos lleva consigo numerosos problemas prácticos y teóricos. En primer lugar, el verbo acontecer proviene de su variante en desuso contecer, derivado a su vez del latín contingere, y es decir, contingencia, lo que no es universal ni necesario; lo deducible desde el presente generando una hipótesis histórica. De allí se desprende una modalidad específica de historicismo retroactivo: aquella que crea acontecimientos a partir de los hechos. En este sentido, Popper (2014: 29) señala que el historicismo (corriente filosófica que cree en la predicción histórica) "afirma que nada tiene mayor importancia que el nacimiento de un período realmente nuevo". Dicho esto, todo discurso, lejos de representar los hechos a los que alude, los reproduce, construye el acontecimiento, resignificándolo, filtrándolo por una mirada, una ideología. Este proceso de significación que convierte lo contingente y particular (el hecho) en universal y necesario (el acontecimiento) está condicionado y posibilitado por la narración. Así pues, "la trama es la mediadora entre el acontecimiento y la historia. Lo que significa que nada es un acontecimiento si no contribuye al avance de una historia" (Ricoeur 1997: 481), la de (cierta) España y (cierta) América. Todo esto teniendo en cuenta que los relatos se basan a su vez en otro metarrelato: el de la invención/conquista del nuevo continente, que se toma como fuente principal.

Estas películas traman propuestas narrativas, fabulaciones sobre el presente, por medio del pasado. Profundizando en esta idea, Lévi-Strauss (1995: 218) sostiene que "la técnica del relato busca, pues, restituir una experiencia real". Este carácter mítico se ve asimismo reflejado en los filmes que hemos analizado: la dialéctica entre la cultura y la naturaleza (Greimas 1973: 167). Esa restitución mitificada utiliza a los protagonistas de la llegada a América para narrar una historia, "similar a la real", pero basada en el presente. Todas las civilizaciones conocidas han necesitado narrar para construir su identidad, dando sentido a su vida, escribiendo una historia de ellas mismas y, por ende, de sus historias. A ojos de Hayden White (1992: 11), "la narrativa [...] supone determinadas opciones ontológicas y epistemológicas [...] e incluso específicamente políticas". Asimismo, Barthes (1970: 9) apuntó la imposibilidad antropológica de una cultura sin historias: "no hay ni ha habido jamás en parte alguna un pueblo sin relatos". Desde la perspectiva del presente las películas históricas "tienden a comprimir el pasado [...] normalmente con una sola interpretación" (Rosenstone 1995: 22). Esto nos conduce a nuestra hipótesis principal: la narrativización ficcional de hechos históricos es correlativa a una politización de los contenidos y las formas empleadas. 
Dicho esto, no parece descabellado plantear la idea del visionado de un filme como una suerte de ejercicio retórico-audiovisual para convencer a un "auditorio" contemporáneo. El cine se presenta como una herramienta programática más de los intereses de un Estado o conjunto de naciones, para afianzar sus cimientos ideológicos y sociales. Es decir, un arte y, a la vez, un medio de comunicación gregario y público al servicio de un beneficio particular; ideología (teoría, o el contenido y el argumento de un filme) y política (praxis, donde entraría el lenguaje cinematográfico que lo articula). Porque "las imágenes no son inocentes" (Camarero 2002: 5), ni neutrales; a todo plano que recorta la realidad antecede una postura que determina el sentido de la imagen.

\section{LA MIRADA MESO- Y NORTEAMERICANA: RETORNO A AZTLÁNY APOCALYPTO}

Esta parte de la investigación estudia dos películas rodadas completamente en náhuatl, ambientadas en el período prehispánico tardío. Ambas abordan la conquista de América focalizada en los nativos americanos desde perspectivas opuestas al tiempo que complementarias: Retorno a Aztlán de Juan Mora Catlett (1990) y Apocalypto de Mel Gibson (2006). Este análisis comparativo presta atención a una mirada que puede tildarse de "puramente" americana sobre la representación realizada acerca del asunto que nos ocupa. Tratadas desde una posición poética y otra comercial, ayudarán a configurar aquello que Navarrete-Linares (2018: 11) define como "la cosmovisión y el mito [mesoamericano], [para] [...] abrir nuevos caminos de interpretación y comprensión”.

Retorno a Aztlán responde a una necesidad artísticopolítica por parte de algunos intelectuales mexicanos. Cabe sugerir que, con este filme, Mora Catlett recoge la herencia de la tradición de los pintores muralistas surgidos durante la primera mitad del siglo $\mathrm{xx}$, algo que ya trabajaron Sergei Eisenstein y Grigori Aleksandrov en el filme maldito e incompleto ¡Que viva México! (1932), en tanto que ambas obras retratan escenas pintorescas de las tradiciones indígenas y de la geografía mexicana (Albano 2008: 152) con una tonalidad general de marcado carácter sociopolítico y revolucionario. Tal como afirma Mignolo (2010: 14), Mora Catlett monta un ensayo fílmico erigido sobre una "reconstrucción y restitución de historias silenciadas, subjetividades reprimidas, lenguajes y conocimientos subalternizados". Retorno a Aztlán "muestra la posibilidad de [...] trabajar con la memoria colectiva, hacia un reconocimiento del pasado que no produzca desconocimiento y alienación" (Rosenstone 1995: 17). Mora Catlett afirmó que su obra satisface la idea de realizar un cine que "en su tema, materia y forma estuviera profundamente enraizado en su cultura [...] Así, la dramaturgia mexicana tiene que nacer del análisis del mito mexicano [...] el más antiguo de los mitos prehispánicos" (citado en Amit 2017: 8).

Apocalypto, por su parte, es una película que puede pensarse en términos de "anticonquista" (Pratt 2011; Méndez Mihura 2019: 6). Concretamente, se plantean las trágicas consecuencias que trajo consigo la ocupación y el dominio de un continente ya en declive. El propio relato abre con la cita del historiador y filósofo William Durant: "Una gran civilización no es conquistada desde afuera sin que antes no se haya destruido desde adentro". Así, Gibson edulcora la Leyenda Negra española ${ }^{1}$ " "para ello se escuda en la crueldad del imperio precolombino" (Méndez Mihura 2019).

\section{Retorno a Aztlán}

Juan Mora Catlett ha oscilado entre los cortometrajes de ficción y los documentales. Ello queda plasmado en sus largometrajes, que destacan por el equipo de rodaje ligero, el bajo presupuesto y el tratamiento poético-mítico de sus historias. Este filme no llegó a impactar a nivel global, ya que se aleja de los estándares de cine comercial (Ebel 1996: 14), amén de que no es apto para un público no iniciado en estudios, historias y narraciones mesoamericanas. El argumento no se comprendería sin un previo conocimiento del mito de Aztlán, que relata el éxodo de sus habitantes hasta Tenochtitlán (Ciudad de México), donde finalmente se establecieron (Castañeda de la Paz 2005).

Mora Catlett sacrificó los réditos económicos de este filme en beneficio de una independencia creativoartística que ofrecía el cine independiente. Así, entendiendo "sacrificar" como el acto de hacer algo sagrado, esta película sacraliza cinematográficamente lo relatado en La tira de la peregrinación. De hecho, la fórmula empleada por Mora Catlett para denunciar el poder de las élites y la manipulación histórica consiste en exhibir y esconder el sacrificio. Primero, porque no muestra explícitamente ninguno: el protagonista -Ollin, joven miembro de una tribu- debe sacrificarse por los suyos, 


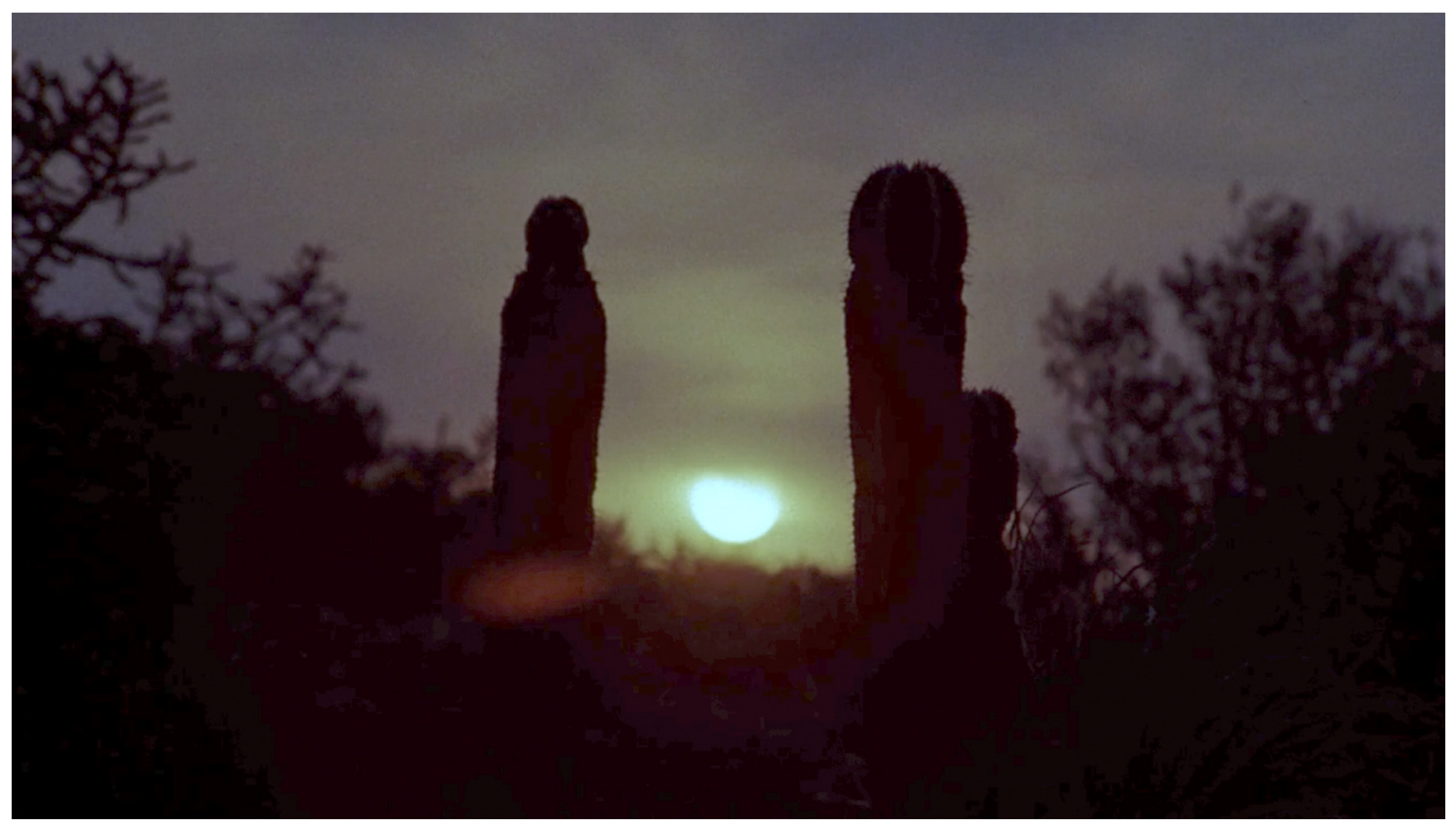

Figura 1. Fotograma de Retorno a Aztlán (Mora Catlett 1990). El sol juega un importante papel simbólico respecto al nacimiento y muerte de los imperios. Figure 1. Frame of Retorno a Aztlán (Mora Catlett 1990). The sun plays a significant symbolic role, representing the rise and fall of empires.

encaminándose hacia un viaje a Aztlán del que, contra todo pronóstico, sale ileso. Y, además, porque, en lugar de ser recompensado, es asesinado; es decir, sacrificado.

Deconstruyendo el éxodo que hicieron sus ancestros, Ollin debe rehacer los pasos de sus antepasados para alcanzar el origen de su civilización, entregar una ofrenda a Coatlicue, madre del dios guerrero Huitzilopochtli, con el fin de detener la sequía que está provocando problemas económicos (falta de alimento), sociales (reproches a las élites mayas) y religiosos (ofrendas a otras deidades). Al final alcanza su objetivo, trae de vuelta las lluvias y lleva a las autoridades de Tenochtitlán el mensaje de la diosa madre: está enfadada por haber sido abandonada y por el ansia bélica de Huitzilopochtli. Tras su asesinato, Ollin accede al mundo de las deidades y, en común acuerdo, deciden que sea el sucesor de Moctezuma, el nuevo y quinto sol, "el del movimiento", en homenaje a su odisea. De hecho, su arco de transformación refleja la evolución que vivió la comunidad maya: "Aztecas eran los pobladores de Aztlán; como mexitin se reconocieron durante la peregrinación y mexicas cuando adoptaron su condición guerrera" indica Stoopen Galán (2015: 144-157). Al igual que Ollin, esta civilización pasó de pacífico-nómada a bélico-sedentaria.
Durante su solsticio-reinado, Ollin destruirá el reino de Moctezuma, en castigo por su carácter opresor. "Este proceso de herencia cosmológica señala la índole cíclica en la que se sitúan tanto el Alpha, Aztlán, como el Omega: Tenochtitlan" (Johansson 2016: 114). Tiene así su eco en la estructura narrativa de la obra, que al igual que los mitos, en lugar de cronológica y lineal, es cíclica. Por ello, la narración se abre y cierra con las deidades y Ollin, situados en círculo, alrededor de la hoguera. Dicha reunión recrea el paso entre el mundo terrenal y el celestial, el portal al mundo de los vivos que, desde el lado opuesto, resulta ser el mismo sol. El montaje muestra primero a Ollin frente a la hoguera, zambulléndose en ella para, en contraplano, mostrar un ocaso enmarcado entre dos cactus que simulan ser pilares (fig. 1). Y es que con el fuego $-y$ la acción de quemar- se buscaba la recreación de un mito cosmogónico para regenerar el mundo (Nájera Coronado 2019: 91).

Por este motivo, a medio camino se hallan los sacerdotes y brujos mayas, quienes enlazan el mundo físico con el espiritual. Signo de esa posición intermedia es el maquillaje que los divide verticalmente. Alegóricamente, expresa el medio sol que Mora Catlett filma 


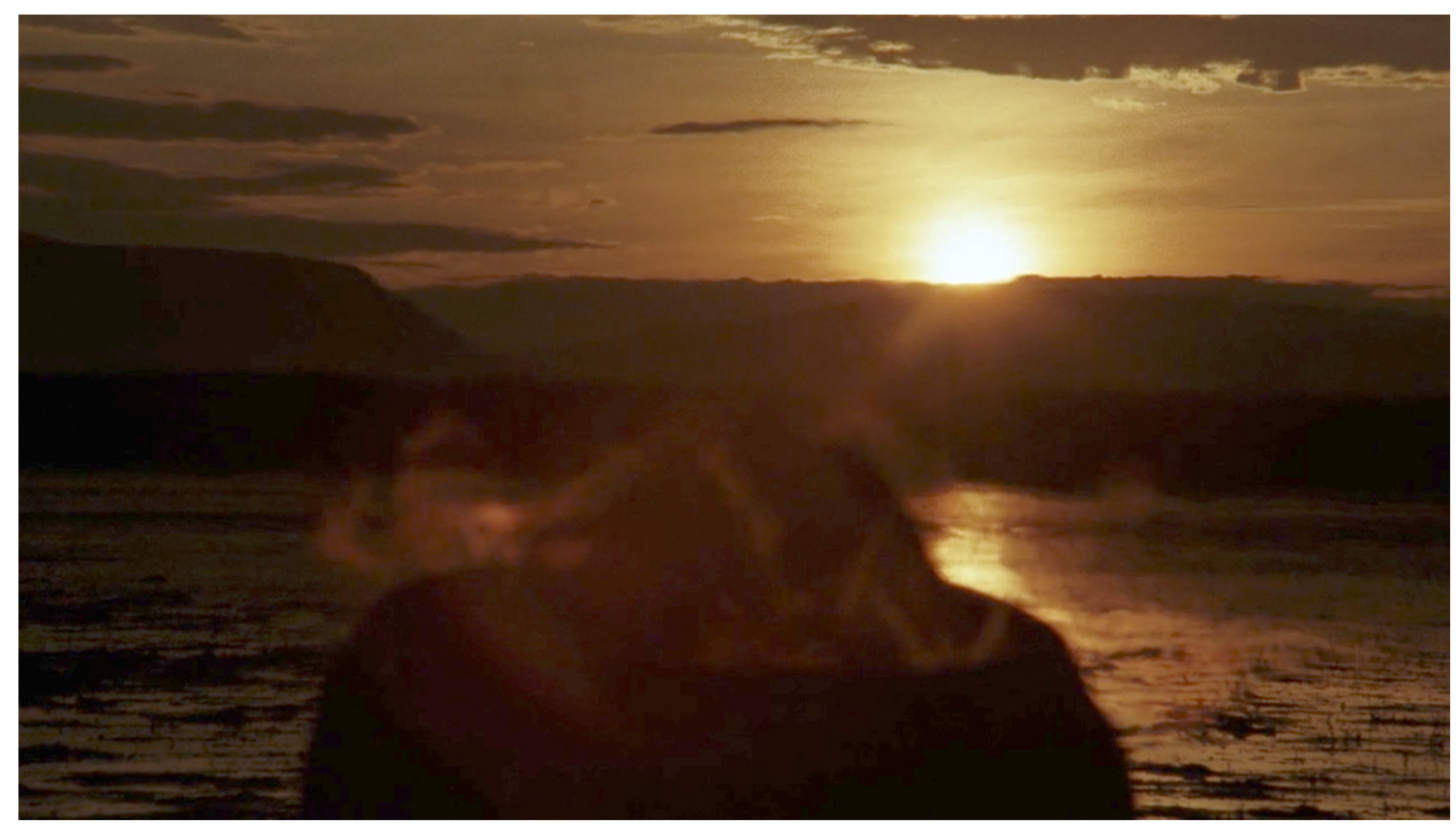

Figura 2. Fotograma de Retorno a Aztlán (Mora Catlett 1990). El fuego, las cenizas y el alba; pasado, presente y futuro; historia y memoria. Figure 2. Frame of Retorno a Aztlán (Mora Catlett 1990). Fire, ashes, and dawn; past, present, and future; history and memory.

en varias ocasiones. El rojo corresponde al astro, a lo divino, mientras que el negro, a su sombra, siempre anexionada a la tierra, a lo humano.

Al final de la cinta, estos hechiceros también alcanzan Aztlán. Se topan con uno de los primeros habitantes del lugar, vestido con harapos y carentes de maquillaje. Se burla de ellos, pues no pueden alcanzarlo mientras sube hasta lo alto de un cerro. Luego regresa rejuvenecido, mostrando su inmortalidad, su condición atemporal: una encarnación del mito. Los que se quedaron en Aztlán y no salieron a guerrear son los auténticos descendientes de los dioses y, como ellos, inmortales. Este hombre les entrega un taparrabos modesto para que Huitzilopochtli lo vista, como seña y recuerdo de sus orígenes.

Esta superioridad, humilde e inquebrantable, es una alegoría política que la película no se molesta en ocultar. Todo este conflicto económico-religioso, articulado mediante transgresiones narrativas y escenificaciones etéreas, es la herramienta de Mora Catlett para construir su discurso ideológico: narrar la historia de las naciones emergentes (re)creando una nueva imagen y los valores que correspondían a sus proyectos, como aquellas obras chicanas del siglo xIx; en especial, la novela Peregrinos de Aztlán (Méndez 1974), cuyo fin era "plasmar la historia de un pueblo para darle legitimidad y conciencia, apro- ximándose en este sentido a las ficciones fundacionales" (Páez Lotero 2019:24), haciendo de Aztlán la Jerusalén mesoamericana.

El último plano de película expresa formalmente todo lo expuesto con anterioridad. El brasero, aún humeante, en el que Tlacaélel (consejero de Moctezuma) ha destruido la memoria documentada de Ollin (para que nadie conozca sus hazañas, impidiendo así que la historia lo reconozca como verdadero salvador de su cultura, honor atribuido injustamente a su rey) se alinea horizontalmente con un sol naciente, un nuevo dios surgido de esas cenizas redentoras, que ahora desaparecen. Estas representan la memoria que se desvanece, el pasado; el humo equivale al presente y el alba apocalíptico es aquí el futuro. Quedan ordenadas, así, en un mismo encuadre, las tres formas del tiempo (fig. 2). Ahí radica exactamente la denuncia de Mora Catlett contra la manipulación histórica de las élites de las naciones.

Sin embargo, Ollin tiene que luchar para derrotar a Moctezuma. El rey maya, maquillado de color azul y atribuido con el escudo de plumas y la espada de sílex -tal y como corresponde a los motivos iconográficos de Huitzilopochtli (Sahagún 1963 [1577]), dios padre de la guerra maya-, reconoce en lo alto del firmamento a este 

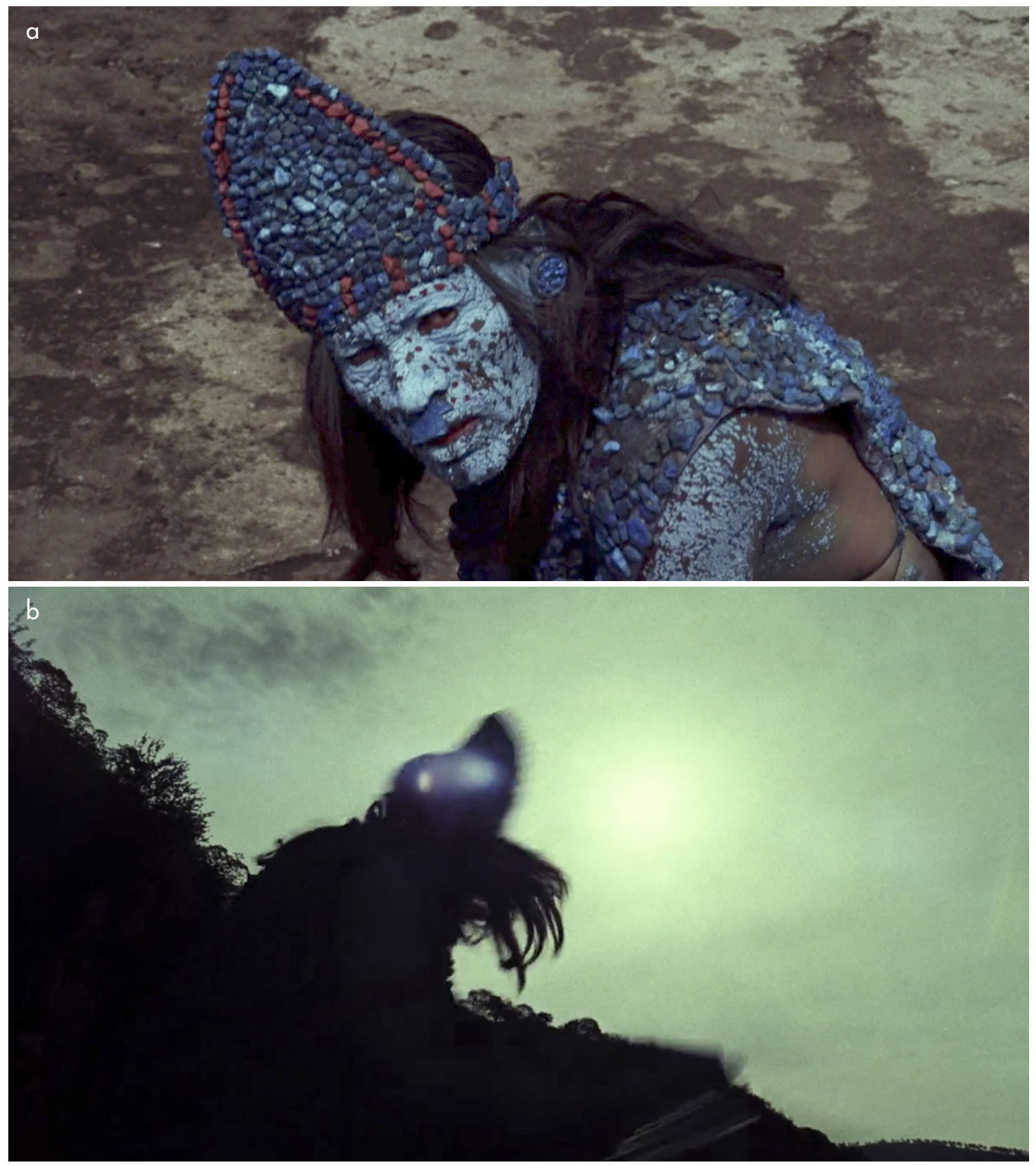

Figuras 3. Fotogramas de Retorno a Aztlán (Mora Catlett 1990): a) Moctezuma cegado por los rayos del Sol; b) los rayos se imponen a la sombra de Moctezuma. Figure 3. Frames of Retorno a Aztlán (Mora Catlett 1990): a) Moctezuma blinded by the Sun's rays; $\boldsymbol{b}$ ) the rays prevail over Moctezuma's shadow.

nuevo dios Ollin, su enemigo. Unos tambores de guerra dan cuenta de la batalla simbólica que está celebrándose, más allá de lo meramente visual, una lucha alegórica entre este joven y resplandeciente sol y el anciano y encorvado rey, apodado "el viejo", a quien vence. El contraluz expresa plásticamente esta confrontación entre luminosidad y oscuridad. Los rayos abrasan y ciegan a Moctezuma, se imponen a su sombra. Él intenta defenderse con sus armas, pero es finalmente derrotado y se desploma, dando paso a una nueva era (fig. 3). 
Retorno a Aztlán plantea una crítica a la situación de aquellos mexicanos que han emigrado a Norteamérica -comprendida aquí como la nueva Tenochtitlán- en aras de mejorar su situación económico-social, porque "ya no creen que la economía mexicana vaya a mejorar y, aun cuando lo hiciera, la elite mexicana se apropiaría de la nueva riqueza. Estos inmigrantes saben que "la marea alta no salva todos los barcos"' (Smith 2002: 5). Es, a su vez, inevitable asociar Aztlán con el movimiento chicano y su lucha por mejorar las condiciones de vida de sus gentes (Maciel et al. 1980: 105), en pos de crear un "Nuevo-Nuevo Mundo". Mora Catlett parece sumarse a ellos en esta denuncia en contra del imperialismo del pasado mexica.

El filme mexicano expone la situación de una sociedad decadente por culpa de la gestión de la élite regional (ejército y religión). La población decide huir de los núcleos urbanos, por ello las ciudades se muestran vacías y semiderruidas, como si las ruinas en las que fueron rodadas las escenas perteneciesen al contexto real y sincrónico del relato. Hombres como Ollin deben realizar un éxodo hacia tierras desconocidas, sorteando los graves peligros que aparecen al paso con la única intención de obtener una oportunidad de mejorar el entorno económico-social de la gente que se ha visto obligada a dejar atrás. Mora Catlett logra realizar una denuncia en clave artístico-política, aunando una nueva forma de arte más propia de las inquietudes y de la cultura de su nación. Esto es, una manera mexicana de hacer cine para tratar temas sociales, políticos e intelectuales propiamente mexicanos.

\section{Apocalypto}

Apocalypto cuenta la partida y el regreso de Garra de Jaguar (protagonista), miembro de una tribu de cazadores que habitan aislados en lo más profundo de un bosque tropical mesoamericano. Mientras tanto, la civilización maya se ha impuesto por la fuerza y amenaza al resto de las pequeñas comunidades que pueblan la zona. Garra y sus compañeros cazadores tropiezan con una tribu vecina empujada al éxodo, "infectados con el miedo", tal y como señala Cielo de Sílex (padre del protagonista). Su aldea ha sido devastada por unos asaltantes militarmente superiores. A la mañana siguiente, Lobo Cero -líder del grupo maya encargado de secuestrar hombres para los sacrificios rituales de su pueblo- asesina a Cielo de Sílex, destruye la aldea y rapta a los hombres más jóvenes. Antes de ser derrotado, Garra esconde a su mujer embarazada y a su hijo en el fondo de un pozo. Tras sobrevivir a la huida del hogar, logra evadir la muerte y abandonar la ciudad maya, asesinando antes a Roca Pulida cuyo padre, Lobo Cero, emprende una persecución contra él, que retorna a la selva, su hogar. Garra vence a sus perseguidores y rescata a su mujer, que ha dado a luz en mitad de una tormenta que ha estado a punto de ahogarla.

La preservación de la naturaleza, la cooperación, la unidad familiar y la lucha contra la explotación de los recursos naturales son temas que aborda la cinta de Gibson (2006). En ella destacan dos espacios claramente delimitados que, junto al resto de disposiciones narrativas y formales, confrontan todo aquello relacionado con la naturaleza, comprendida aquí como selva amazónica, y la civilización, plasmada en la ciudad maya. Un juego de constantes simetrías vertebra la estructura de la narración, contraponiendo dos estilos de vida que, si bien comparten un mismo continente, nada más tienen en común respecto de su contenido. Sin valorar el discurso histórico-filosófico propuesto por Gibson, Lacadena (2007: 250) pertenece a la corriente que opina que:

\footnotetext{
Apocalypto no hace más que reproducir [...] el tópico renacentista de la excelencia de la vida natural frente a la urbana, la idea ilustrada [...] de la superioridad moral y cultural de los occidentales justificadora del colonialismo, todo ello hábilmente aderezado con la recientemente adquirida sensibilización ecológica: [...] la satisfacción de las necesidades materiales de la civilización urbana lleva a la destrucción del medioambiente y a la alienación del ser humano.
}

Todo guarda un significado vinculado al sujeto dominador y al objeto dominado, pues, en esta narración, una vez que un ser vivo es capturado, pasa de ser "humano" a ser "sacrificado". Una variable marca la identificación de cada elemento: el miedo que, en su transcurso pendular, pasa de un bando al otro. Cielo de Sílex advierte: "el miedo es una enfermedad que pudre el alma”. Esta máxima articula tanto los actos heroicos como los crueles de la cinta de Gibson.

Así se muestra al decadente, masificado y explotador Imperio maya, "los hijos del Sol", como se autodenominan. Una gran sequía ha provocado una fuerte crisis de la que, presuponen, solo podrán salir compensando la falta de agua con sangre de los sacrificios. Estos se celebran en lo alto de los templos piramidales, lo más cerca posible de su divinidad solar en su eje más vertical: 


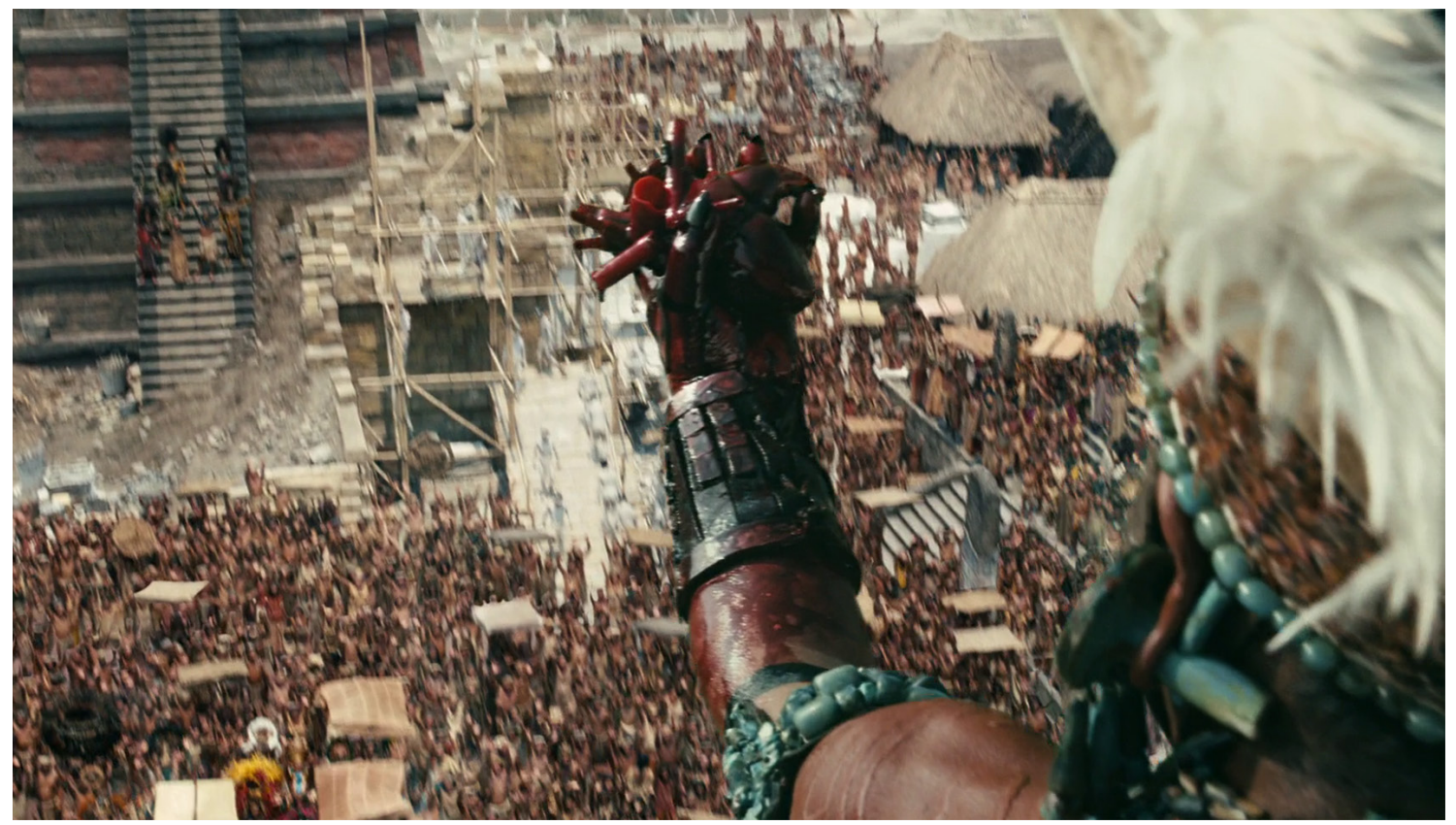

Figura 4. Fotograma de Apocalypto (Gibson 2006). El corazón y el pueblo coinciden en un mismo espacio. Ambos mantienen vivo el ritual sacrificial. Figure 4. Frame of Apocalypto (Gibson 2006). The heart and the people happen to be in the same space. Both of them keep the sacrificial ritual alive.

al mediodía. Deben abastecer diariamente a la divinidad con vidas y, sobre todo, con corazones. Este último se lo otorga su chamán, en muestra de respeto, de jerarquía, el mayor honor es otorgar el corazón. En cierto sentido, parece que estos acontecimientos alimentan también la esperanza del pueblo, por eso la cámara se sitúa de manera que el gentío y el corazón despojado quedan encuadrados en un mismo plano (fig. 4). Es decir, los sacrificios son el corazón del pueblo, pues lo bombean y lo mantienen "vivo".

Por esto mismo, al comienzo de la obra la cámara se adentra en el corazón de la selva, la auténtica protagonista. En la oscura profundidad se escenifica una partida de caza liderada por Garra de Jaguar y los suyos. Rana de Humo -el más valiente- recibe el corazón, y Torpe-el menos respetado-, los testículos del animal, para sanar su cobardía. Esa falta de valor es una forma de miedo que poco a poco irá contaminando el alma de toda la tribu, infectando primeramente a Garra, tal y como su padre diagnostica, tras encontrarse con la tribu vecina despojada de su hogar.

En esta tribu, la disposición formal que adoptan todos los miembros los sitúa en un mismo estrato social, esto es, en un círculo alrededor de una gran hoguera, símbolo de su unión como comunidad, y a un mismo nivel, a los pies de la naturaleza. Esto a diferencia de la ciudad maya, pues las pirámides -con sus ángulos rectos, altura y majestuosidad son símbolo de la disposición jerárquica de su sociedad, dividida entre lo superior y lo inferior, lo divino y lo terrestre o, sencillamente, las élites (hombres religiosos y monarquía) y el pueblo llano. Aunque ellos se consideran hijos del Sol, la aldea de Garra de Jaguar se erige como hija de la Luna, ya que bajo su luz consultan a sus dioses en busca de consejo. Además, el líder espiritual de la tribu es manco -su don está en la palabra, no en las armas-, hecho formal que contrasta con el gran cuchillo ceremonial que empuña el chamán maya.

De hecho, si bien la cima de la pirámide es el lugar de las ejecuciones, la muerte, el peligro o la violencia más expuesta, lo contrario ocurre con el pozo en el que el protagonista esconde a su familia. Del mismo modo que la madre preserva la vida de su hijo nonato, el otro -Paso de Tortuga- también es protegido bajo un útero velador, pues el pozo en el que se hallan, contrapuesto a la cuadrangular pirámide, es profundo, oscuro, circular: el lugar de la paz y la protección, el vientre de la selva. Incluso la grieta que abre esta cueva, en su estrechez 


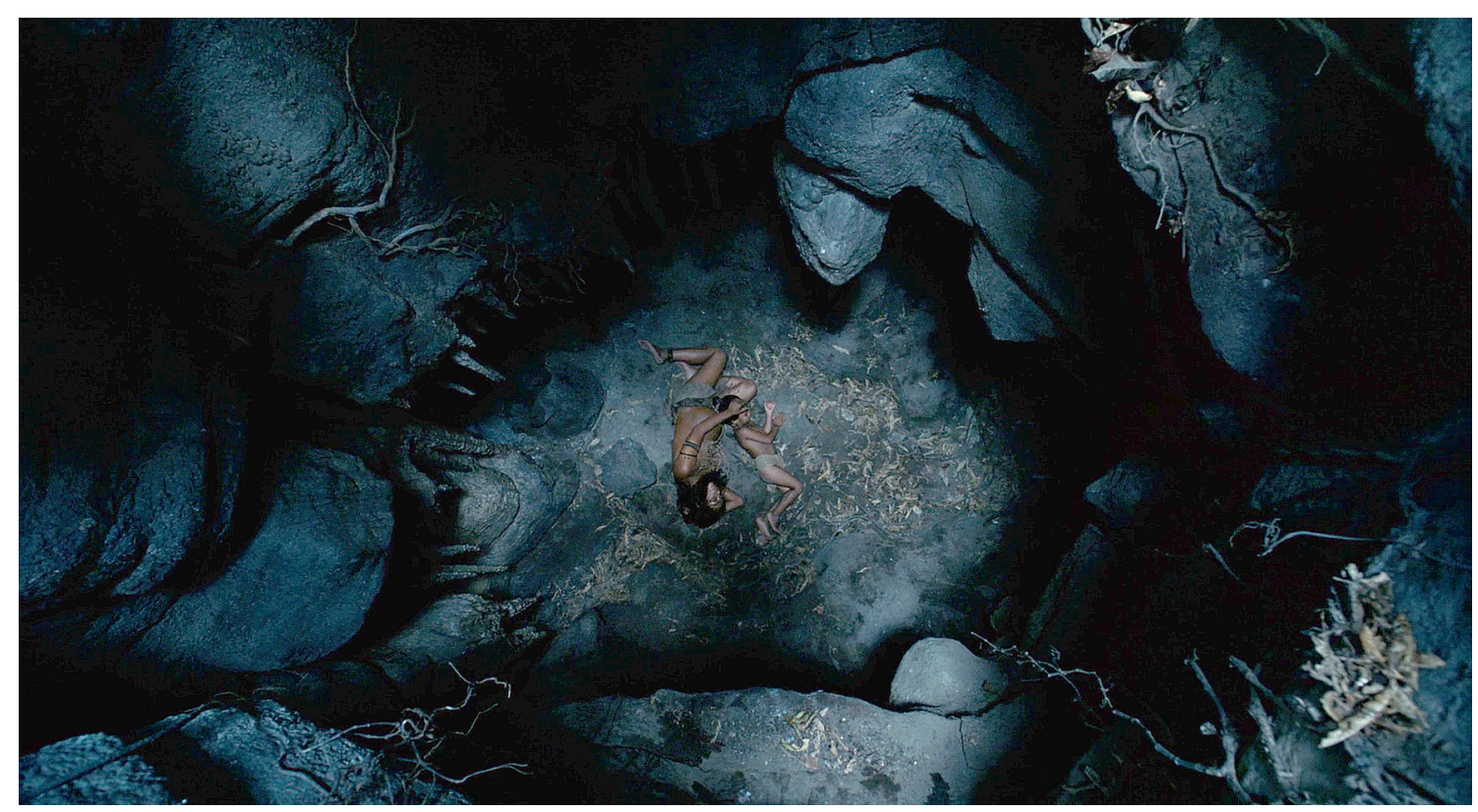

Figura 5. Fotograma de Apocalypto (Gibson 2006). La cueva, el útero materno, lugar de la paz y la protección. Frame of Apocalypto (Gibson 2006). The cave, the mother's womb; a place of peace and protection.

y horizontalidad, guarda forma similar al órgano reproductor femenino, el cual choca con la verticalidad fálica de la estructura piramidal (fig. 5). De esta forma, lo masculino queda conectado a lo bélico, destructor y mortal, y lo femenino a lo pacífico y vital. En definitiva, la extinción enfrentada a la reproducción.

Todos estos motivos sirven para comprender el augurio que una niña infectada profetiza contra los soldados mayas mientras llevan a Garra de Jaguar y al resto de cazadores a la pirámide sagrada. "Guárdate de la oscuridad del día [...] El día será noche y el hombre jaguar os conducirá a vuestro fin", les advierte refiriéndose al eclipse que se avecina. Y es que durante el sacrificio al que están a punto de someter al protagonista, un acontecimiento inusual tiene lugar: el eclipse solar. La muchedumbre -antes expectante, eufórica, ruidosa y sedienta- se torna silenciosa, inquieta y temerosa ante el fenómeno. Efectivamente, la luna oculta al sol, la luz da paso a la sombra, esta ocupa su lugar: la luna reclama la vida de uno de sus hijos. El chamán lo comprende y detiene el ritual. Pese a que estos mayas son vinculados con la luz del sol, la claridad y la violencia como espectáculo, Garra de Jaguar y los suyos pertenecen a la sombra, la oscuridad y la intimidad. De este modo, el miedo, esa enfermedad que pudre el alma, comienza a cambiar de bando, como bien señalaba Cielo de Sílex. El arco de transformación que vive Garra de Jaguar comienza a producirse gracias al eclipse total.

Entonces los prisioneros son liberados y se les permite marchar si pasan por una prueba de puntería, organizada por Lobo Cero como entretenimiento. Garra de Jaguar es el único que logra huir, no sin la ayuda del moribundo Torpe que, en un último acto de abnegación, auxilia a su compañero y entre ambos abaten a Roca Pulida, último impedimento en el camino a la salvación. Esta escena es la otra cara de la moneda que supone el concepto de sacrificio, más digno que el expuesto en escenas anteriores. Al verlo, Lobo Cero emprende una persecución hacia lo profundo de la selva, buscando vengar el asesinato de su hijo. Esta última partida de caza rima con la vista al comienzo de la obra, la organizada por Garra, solo que, en este caso, el cazador se ve ahora en el papel de la presa, rol que anteriormente se ha repetido. En efecto, en el paralelismo que situaba a Garra de Jaguar y los suyos, apresados y atados al igual que ellos hicieran con el animal (un jabalí) en la salida de caza del día anterior, pasan repetidamente de cazadores a presas.

Una vez dentro de su hogar, la selva, Garra toma la iniciativa y se cierra su arco de transformación, for- 

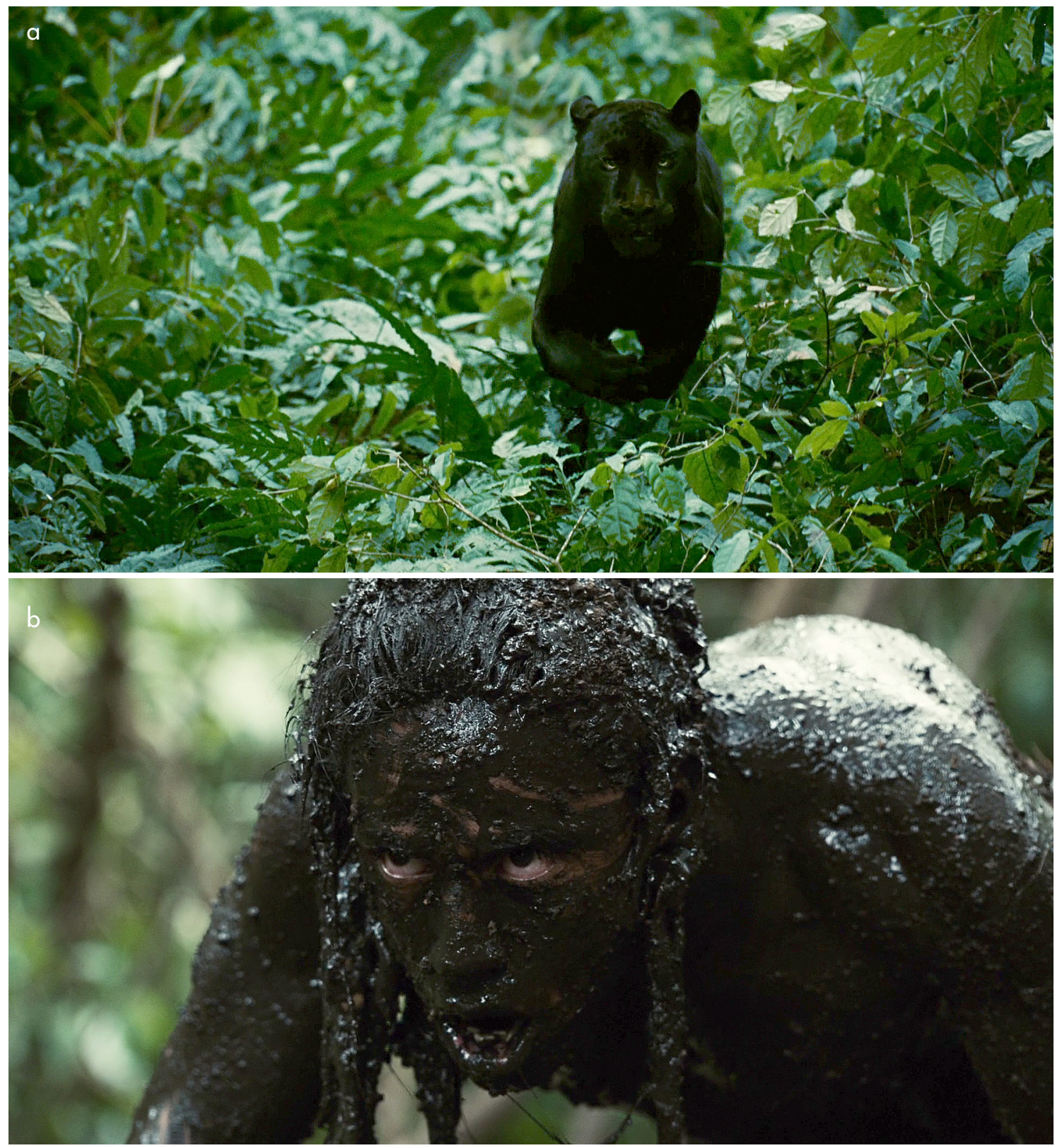

Figura 6. Fotogramas de Apocalypto (Gibson 2006): a) el jaguar, guardián de la selva y de la noche; b) Garra renace como el temible depredador. Figure 6. Frames of Apocalypto (Gibson 2006): $\boldsymbol{a}$ ) the jaguar, guardian of the jungle and the night; $\boldsymbol{b}$ ) Garra comes back to life as this fearsome predator.

malmente retratado en la escena donde tropieza en un pozo de lodo que, en lugar de matarlo, lo hacer renacer portando la piel de la pantera (o jaguar): negra, oscura, cazadora, otra hija de la selva y de la noche (fig. 6). Un soldado de Lobo Cero comprende el error cometido, tras ver el cadáver de un compañero bajo las garras de este felino. La niña antes citada les advirtió: "Cuídate del hombre que traiga un jaguar. Considéralo renacido del barro y la tierra".

Garra de Jaguar emplea sus saberes de cazador para acabar con todos sus captores. El miedo vuelve a balancearse, a transmitirse al bando maya. De este modo, 
el Jaguar y el Lobo se encaran en un último duelo que se salda guardando la simetría que ha caracterizado toda la narración: una de las trampas empleadas durante generaciones por Garra y sus ancestros es activada por Lobo Cero, quedando atrapado y muerto al instante. La selva protege al protagonista, al igual que hizo al comienzo alimentando a la tribu.

El final de la persecución coincide con la llegada de nuevos invasores: los conquistadores españoles. La niña lo pronosticó: "el hombre jaguar os conducirá a vuestro fin". Así pues, en la playa -el límite del mundo conocido por esta población- Garra de Jaguar asiste al gran cambio en la historia de la cultura mesoamericana. Este giro en los acontecimientos es formalizado mediante un movimiento de cámara de $180^{\circ}$ que rodea y aprisiona al protagonista, mostrando primero a los dos últimos perseguidores de Garra, detrás de él, y finalizando, delante, con una balsa repleta de hombres vestidos en metal, barbudos y venidos en unas naves inmensas.

La gran llegada del hombre occidental está relacionada con la cita de William Durant -mencionada al inicio del análisis- que abre la obra y comparte nexo con la profecía del líder espiritual de la tribu de Garra: "[La tierra dijo] ya no soy nada, nada tengo que dar". Ahí estriba el mensaje político-social que Gibson pretende lanzar al público, en boca del hombre más sabio de la narración: los excesos y la insaciabilidad del ser humano, una crítica metafórica de la cultura occidental contemporánea, formalmente (re)presentada en la cultura maya de la película.

\section{COSTA A LA VISTA: ALBA DE AMÉRICA Y 1492. LA CONQUISTA DEL PARAÍSO}

Las siguientes obras relatan un evento capital en el devenir geopolítico y cultural de Europa, y sobre todo de España y de América. En este punto surge una de las cuestiones que queremos dilucidar: ¿cuál es la razón, el "contexto pertinente" (Courtés \& Greimas 1982: 86), que mueve la producción de obras de ficción acerca de Cristóbal Colón cinco siglos después de los hechos acaecidos?

\section{Amanecer de España, alba de América}

El filme español Alba de América dirigido por Juan de Orduña y estrenado en 1951 comporta una serie de condiciones asociadas a su panorama político y a su industria cinematográfica que deben ser resueltas. En primer lugar, hay que señalar que se trató de un encargo del Instituto de Cultura Hispánica, dependiente del Gobierno, "como respuesta a la 'provocación' que suponía una producción británica de 1949, Christopher Columbus (dir. David Macdonald)" (De España 2002: 66). Previo concurso público, la responsabilidad fue a parar a la Compañía Industrial de Film Español, S. A. (CIFESA), abanderada del cine histórico nacional de "gola y levita” y conocida por ser la productora que contó la historia española en el cine (García Escudero 1970: 149). Por su parte, el aparato franquista emprendió desde sus inicios una cruzada político-cultural fundamentada en un "España contra todos", traducido en una cerrazón económica, y un "España por encima de todos" (Arriba, no Viva España), ilustrado por el ensalzamiento del gran arte español de los siglos XVII y xviII. De este modo, Franco quiso combatir la Leyenda Negra con una Historia Blanca, hablar bien de Colón para hablar mejor, irremediablemente, de España, y de paso dar cuenta de las preocupaciones, miedos y enemistades del Estado franquista de los años cincuenta.

Es evidente que Alba de América, con gran despliegue de medios y producción, cumple las características apuntadas por Pedro Uris (1999: 30) sobre el cine político franquista: la localización de "dilemas de carácter político" en parajes exóticos y lejanos de corte aventurero, con un héroe occidental a la cabeza; una "épica grandilocuente e imperial para contar [...] los hechos del pasado con la voluntad de reinterpretar la Historia al servicio de los intereses del Régimen", de "trascendencia espiritual" y que eleva los hechos y los personajes a la categoría de valores eternos, en manos de salvadores o heraldos (Uris 1999: 40-41).

Ya desde los títulos de crédito iniciales el filme hace una entrada triunfal: impreso sobre unos majestuosos planos de los navíos, Alba de América nos dice que "es una superproducción", afirmación que busca legitimar todo lo que a continuación será relatado. El diseño narrativo del filme estructura sus acontecimientos con una alta fidelidad a las fuentes que documentaron el viaje y con un enfoque casi total en el celebérrimo navegante. La narración otorga primero la palabra a los pensamientos dubitativos de Colón. Sin embargo, inmediatamente esta focalización se suspende. Ante la desconfianza de los marineros hacia su patrón a causa de su nacionalidad extranjera y de su sospechoso optimismo, Pinzón arrebata todo posible control narrativo a Colón 


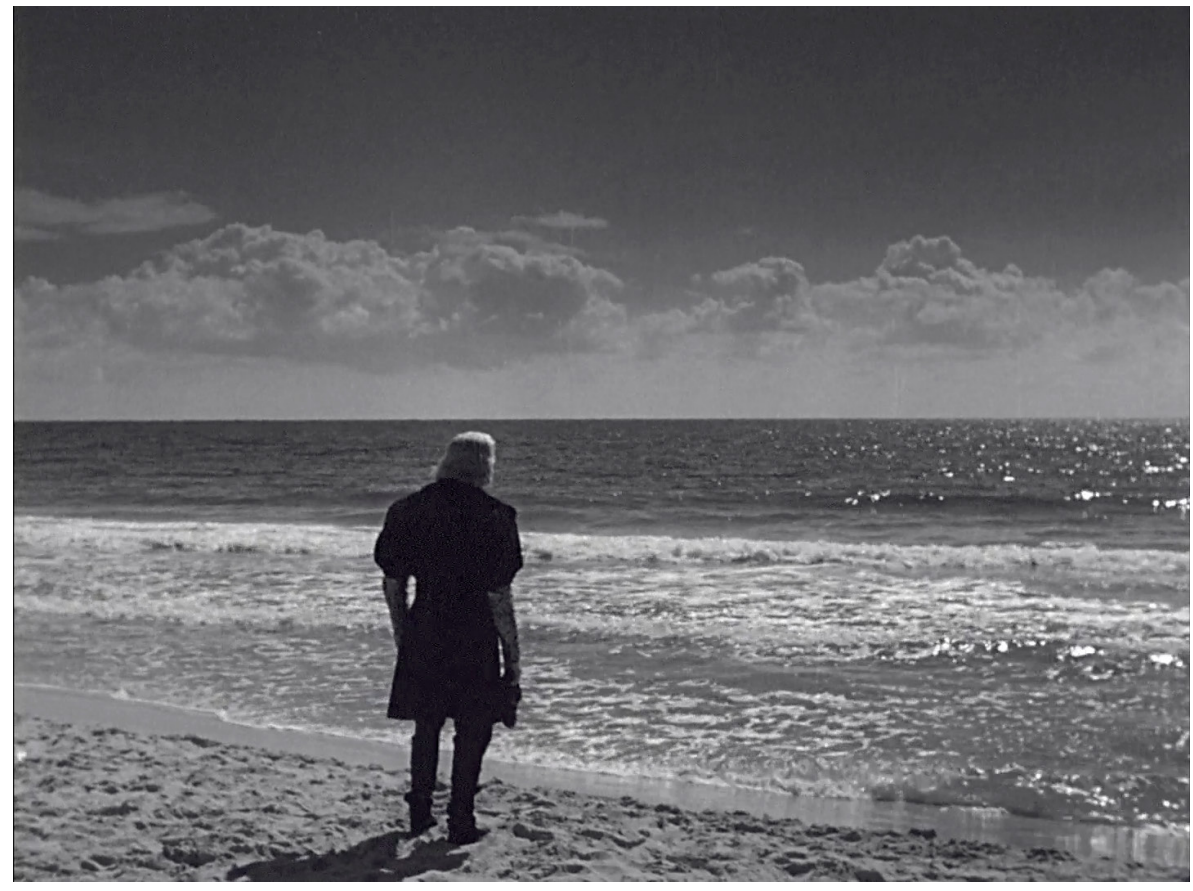

Figura 7. Fotograma de Alba de América (Orduña 1951). Colón se debate entre la tierra y el cielo durante la preparación del viaje. Figure 7. Frame of Alba de América (Orduña 1951). Columbus struggles between earth and heaven during the preparation of his expedition. y se inicia un flashback que va a narrar la historia del genovés desde su llegada a la península hasta la partida en las tres naos. En suma, el relato centrará todos sus esfuerzos en contar al espectador las causas políticas de la expedición, la historia de una lucha administrativa, bélica, contra la ignorancia y la desconfianza del otro, y en narrar la reconquista de los territorios ocupados por los musulmanes. Así se constatan las claras analogías con la guerra civil española, con las que Alba de América quiere excusar también la violencia del frente y la posterior represión del franquismo, alegando la necesidad de la causa española. La voz en off de Colón vuelve al final representada por la escritura de una bitácora. De esta forma, el relato, la historia, pertenece al héroe, porque él es quien escribe y protagoniza la leyenda.

Observemos ahora las composiciones frontales del mar y su unión con el cielo en el horizonte filmadas por Orduña. Estas imágenes, en las que predomina una luz divina que atraviesa las nubes, se utilizan como una especie de transición-presagio del histórico hallazgo. Con estos mecanismos compositivos, Orduña está confiriendo importancia a lo marino o a lo celestial, en función de los avances y retrocesos y los altibajos de la empresa de Colón. Y en el horizonte, donde ambos se juntan, surge el Nuevo Mundo, la nueva España. En consonancia con lo anterior, cuando Colón comienza a orquestar su viaje, en estas vistas el mar adquiere preponderancia espacial sobre el cielo. Más tarde, en un instante decisivo antes de conseguir emprender al fin el viaje, el cuerpo del navegante, en tierra y pensativo, dubitativo, ocupa el espacio compositivo igualado del agua, con el cielo sobre su cabeza. Aunque Colón mire al mar, Orduña (y su cámara) también mira al cielo (fig. 7).

Otro tanto ocurre con la morfología de los mástiles y la manera de encuadrarlos a guisa de una gran cruz cristiana. ${ }^{2}$ A nadie escapará que la suma del mástil (vertical) y la verga mayor (horizontal) dibujan una figura cruzada que preside el centro del barco (fig. 8). De ello se desprende que el palo fundamental que hace moverse al navío no es sino el símbolo del hijo de un Dios que empuja las velas con su voluntad (el viento marino). Para continuar con la representación de motivos cristianos también se puede hallar un recurso fotográfico, basado en la escala del plano y el ángulo de la cámara. Gran parte de los planos que enmarcan a Colón se toman desde abajo, en ligero contrapicado, glorificado. Al lado de esta idea, otra de igual realce: se constata una recurrencia de encuadres cuyo fondo celestial recorta su figura, mientras el navegante entona una de sus numerosas digresiones poéticas y filosóficas acerca de su proyecto: su palabra es la de Dios, que siempre lo respalda (invisible) al fondo de la imagen. 


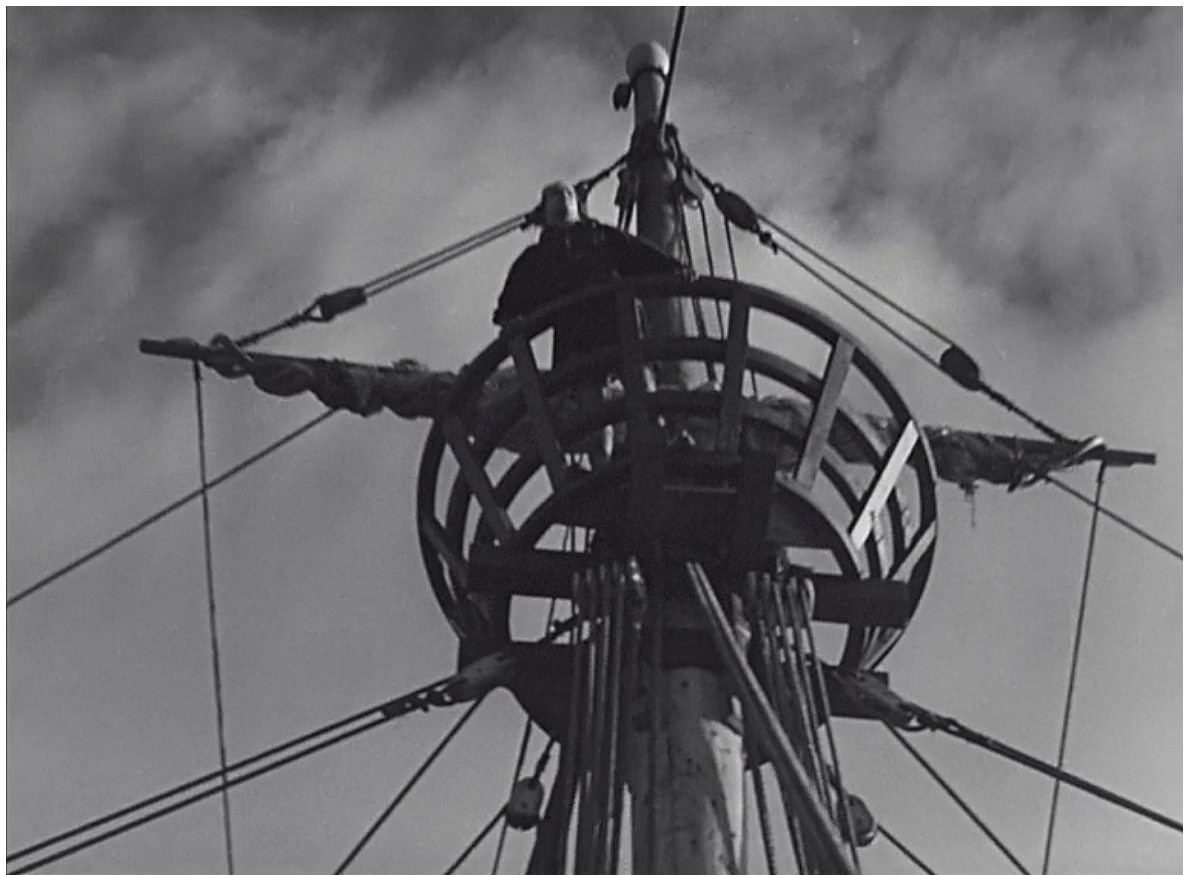

Figura 8. Fotograma de Alba de América (Orduña 1951). Los mástiles y las vergas de los barcos se asemejan estructural y compositivamente a las cruces cristianas. Figure 8. Frame of Alba de América (Orduña 1951). The ships' masts and yardarms resemble Christian crosses in structural and compositional terms.
A efectos narratológicos, es la religión (la fe) la que convence a Colón -en uno de sus pocos momentos de debilidad-de que solo Castilla (España) puede ayudarle. La religiosidad del nacionalcatolicismo se muestra en calidad de "razón última e irrefutable" de los personajes y sirve de modelo narrativo, a modo de calvario que el protagonista debe atravesar para revelar el mensaje (Uris 1999: 40-41). El retrato de Colón es el de un hombre puro que no deja que lo manipulen, desde cuyo nombre se le confiere ya ese poder divino que todo lo resuelve: Cristóbal, el portador de Cristo. En el último plano del horizonte (fig. 9), una sobreimpresión funde la cabeza de Colón con el Sol, donde predomina finalmente el cielo sobre el mar. A este respecto, llama la atención esta exageración del catolicismo del navegante: un héroe cinematográfico católico cuyo cuerpo esplendoroso se torna la superficie idónea para que los espectadores españoles de la época se proyecten y asuman la brújula religiosa y social del régimen.

Cuando se consuma la reconquista (no un final sino un inicio para Colón, un alba) un consejero real dice que "España ya está completa". Sin ánimo de discutir la veridicción del término España, utilizado para hablar del Reino de Castilla, sorprende la manera contundente y extendida con que los diálogos enuncian esa palabra. La representación que Orduña da del sentimiento de
Colón al descubrir América es un ejercicio especulativo, revisionista e historicista. Desde la perspectiva privilegiada del presente puede hacer pensar a un Colón ficticio que su hallazgo fue extraordinario, cuando ni siquiera sabía de las consecuencias históricas, económicas y geopolíticas del acontecimiento.

A fin de cuentas, se puede convenir el sentido implícito en las imágenes de Alba de América: la gesta de Colón en busca del Nuevo Mundo es equiparable, en su desarrollo e historicidad, a la victoria del bando nacional en la contienda de 1936 a 1939: la dominación de un imperio sobre otro, con la del fascismo militarista sobre el pueblo español. Por medio de una doble imposición, religiosa y cultural, sujetada por la fuerza armada, tanto los Reyes Católicos, hazaña de Colón mediante, como Franco (re)conquistaron un territorio en manos del enemigo o del desconocido. Por un lado, narrativizada en la confrontación con Martín Alonso Pinzón, un hombre de ciencia y trabajo, de saber, y Colón, el hombre de la creencia, iluminado por la luz de Dios. Por otro, con la cámara de Orduña que retrata a los indígenas confundidos y animalizados en la selva. De este retrato se desprende la segunda imposición: el proceso de evangelización y civilización experimentado por los nativos americanos, análogo a la imposición castellana ( $y$ franquista) que ordena y bendice en tierras 


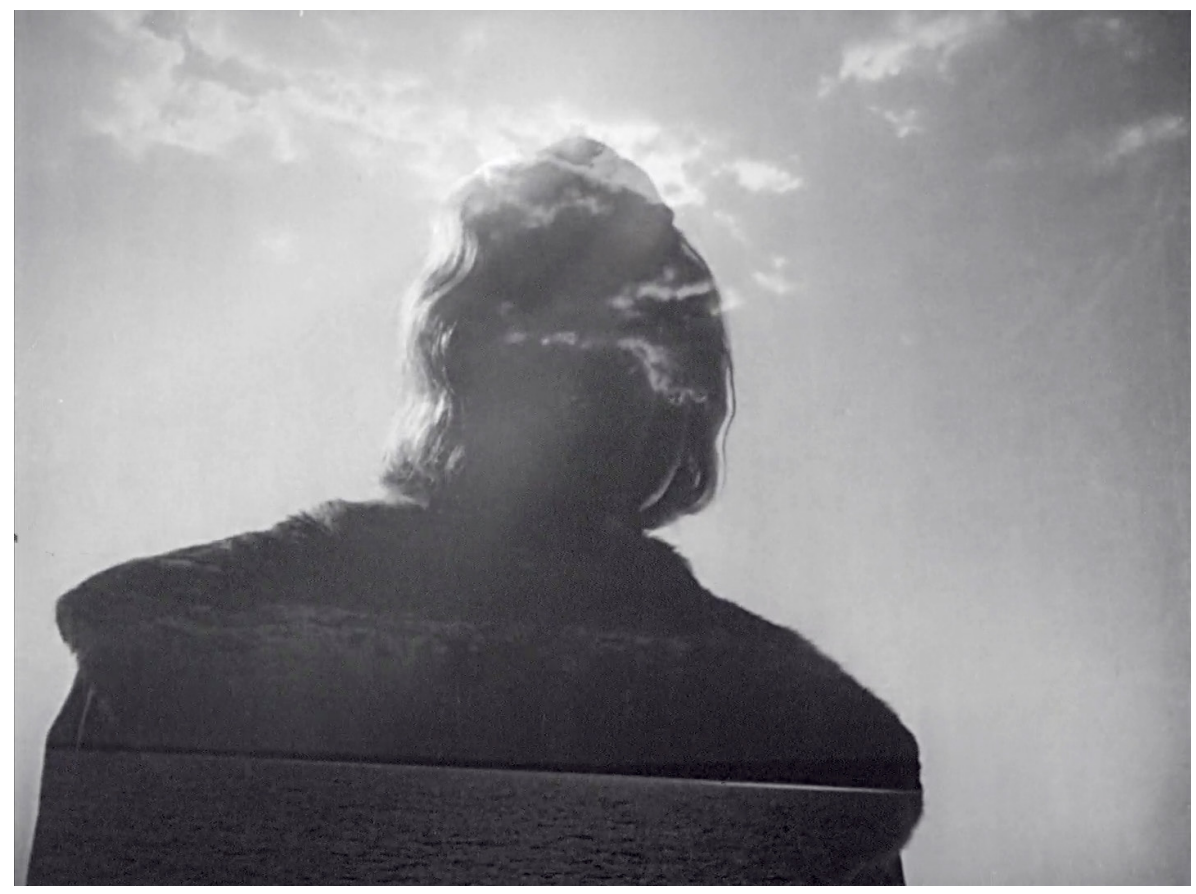

Figura 9. Fotograma de Alba de América (Orduña 1951). La sobreimpresión diviniza a Colón, fundiendo su imponente figura con el sol sobre el horizonte. Figure 9. Frame of Alba de América (Orduña 1951). Columbus is deified by a superimposition, which merges his magnificent figure with the sun over the horizon. plagadas de "enemigos". Dicho de otro modo: la extensión del nacionalcatolicismo por la población y la sociedad españolas de la posguerra y el franquismo.

\section{2: la consolidación del paraíso}

Pese a que 1492. La conquista del paraíso, epopeya dirigida por Scott, es considerada una obra de nacionalidad británica y coproducida entre Francia, España y Reino Unido. El relato se inviste de los ropajes del gran cine épico hollywoodiense. Como bien señala De España (2002), ha resultado históricamente casi imposible que tanto Hollywood -por ser un asunto mayoritariamente hispánico- como las cinematografías latinoamericanas -la herida colonial sigue abierta- dibujen un retrato que magnifique la figura de Colón. Entonces, ¿̇cuál es el sentido histórico y cultural de esta película que contribuyó a la celebración del quinto centenario de la efeméride?

Las palabras que inauguran el relato, escritas a mano y superpuestas a unos grabados que representan escenas cotidianas del Nuevo Mundo, describen a Colón como un héroe divino enfrentado a la superstición y la violencia de la religión católica, "consciente de su destino". Un zoom in penetra en el ojo de un indígena, plano que se funde con un barco en el horizonte. Este navío se encuentra en el absoluto centro de la imagen: el horizonte parte el cuadro en dos casi mitades exactas (fig. 10). Este recurso expresivo, unido al énfasis humanista con que el texto describe a Colón, establecen la base ideológica del relato: un etnocentrismo europeo que une lo terrenal-marino con lo celestial, la ciencia y la creencia.

1492 también conlleva una serie de condicionantes industriales: se ha visto que el texto del principio está escrito en francés, pero el idioma hablado por los actores es el inglés. Asimismo, en algunos momentos se escucha el castellano sin ninguna justificación aparente. Por si lo plástico no fuera suficiente, lo verbal incide en esa idea de Europa como núcleo cultural del mundo moderno: el narrador diegetizado sostiene que el Nuevo Mundo, el paraíso, no existía (eso sí, fuera de la mirada limitada europea que lo inventó).

A Scott no le interesa el antes, sino el durante y el poco después de la conquista, es decir, los elementos épicos. Para explicar a su hijo que la tierra es redonda, este Colón también utiliza una naranja que está pelando. No es baladí señalar que el navegante pela la mitad de la fruta; esto es, divide el mundo en dos mitades, el viejo y el nuevo, "arrasando" este último (fig. 11). En referencia al desarrollo narrativo, se advierte que la trama es muy parecida a la de Alba de América. Lo que cambia es la extensión del contenido y el orden cronológico: en 


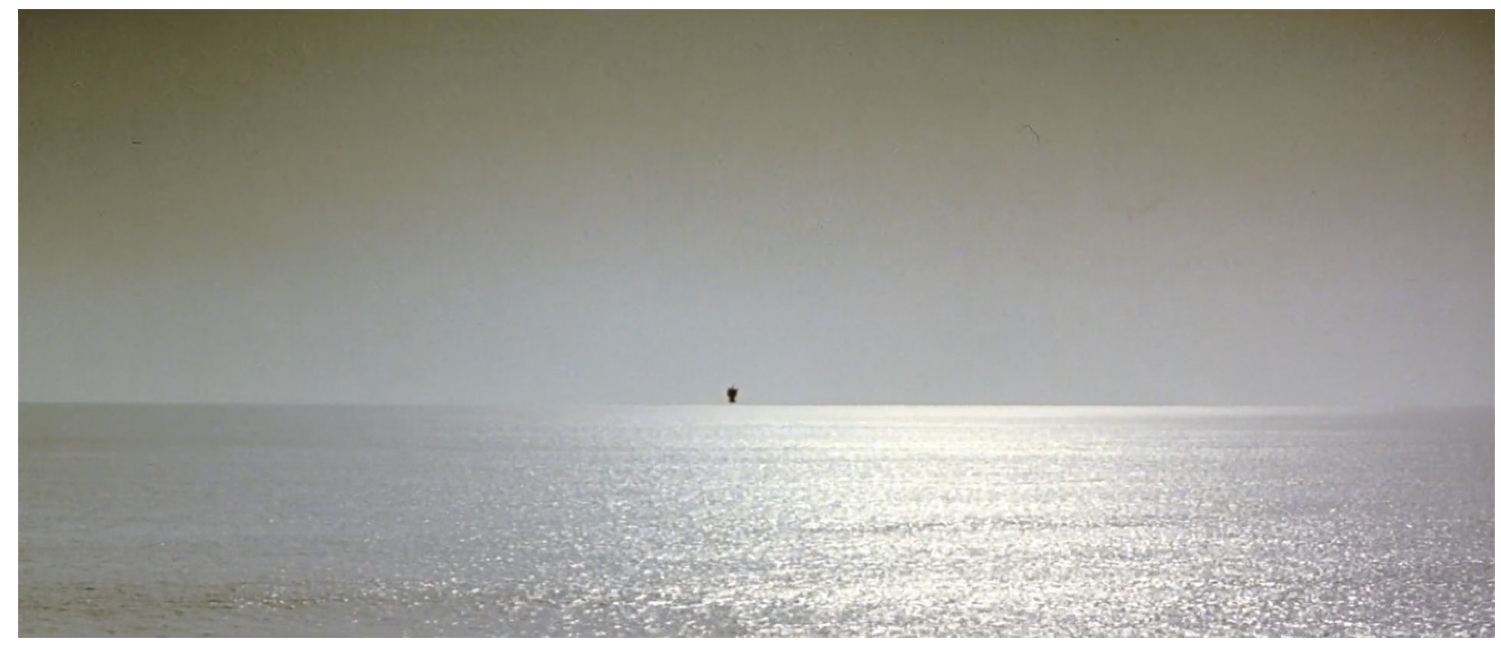

Figura 10. Fotograma de 1492. La conquista del paraíso (Scott 1992). El discurso europeísta del filme sitúa a Colón en el centro del mundo, entre el cielo y la tierra. Figure 10. Frame of 1492. Conquest of Paradise (Scott 1992). The pro-European discourse of the film places Columbus at the center of the world, between heaven and Earth.

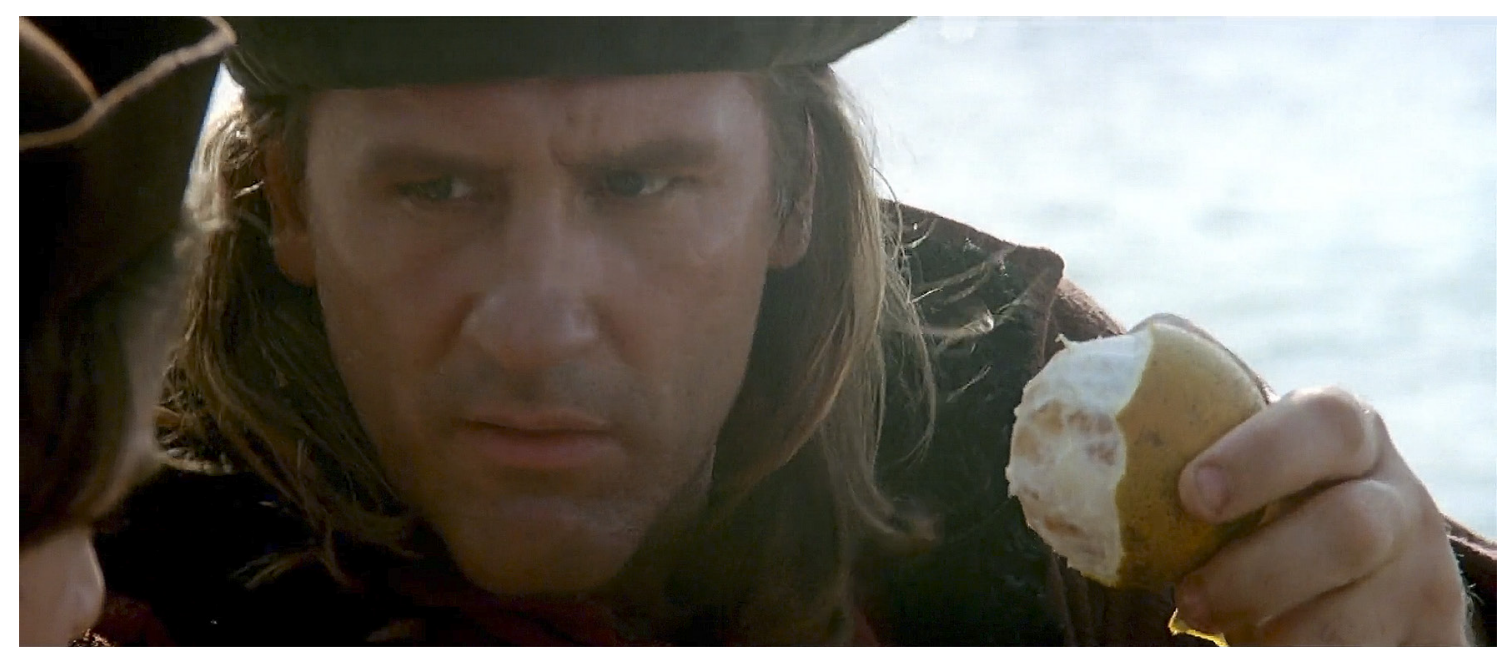

Figura 11. Fotograma de 1492. La conquista del paraíso (Scott 1992). La naranja ilustra el mundo nuevo "arrasado" por el mundo viejo. Figure 11. Frame of 1492. Conquest of Paradise (Scott 1992). The orange represents the new world "devastated" by the old world.

1492 no hay ninguna analepsis, pero también cohabitan dos narradores. El hijo pequeño de Colón, que abre el relato en voz over, y el propio Cristóbal por medio de un diario (al igual que en el filme español). Hasta que la narración no llega al descubrimiento, Colón no tiene voz en el relato. Al final su hijo retoma la responsabilidad: concluye la leyenda y empieza la historia. No obstante, esa crónica fidedigna de los eventos pasados no es tal: el padre dicta ("I remember...", "Yo recuerdo...") y el hijo transcribe. En lugar de asociarlo al testimonio presencial "yo he visto" (Lozano 1987: 15-58), se da un discurso viciado que vincula la memoria imaginativa al saber de primera mano. Como Alba de América, 1492 no se puede resistir a fusionar el hecho y el acontecimiento, la historia (el documento) infalible, contra la memoria (la imagen) falible.

Scott propone un Colón dibujado como un hombre que recela de la religión, más cercano al pensamiento científico, que no cree en fantasías, que desconfía de los religiosos (muy diferente al personaje de Orduña). Al Colón de 1492 no solo le importan el oro y la gloria, sino también la apertura y el pistoletazo de salida que 


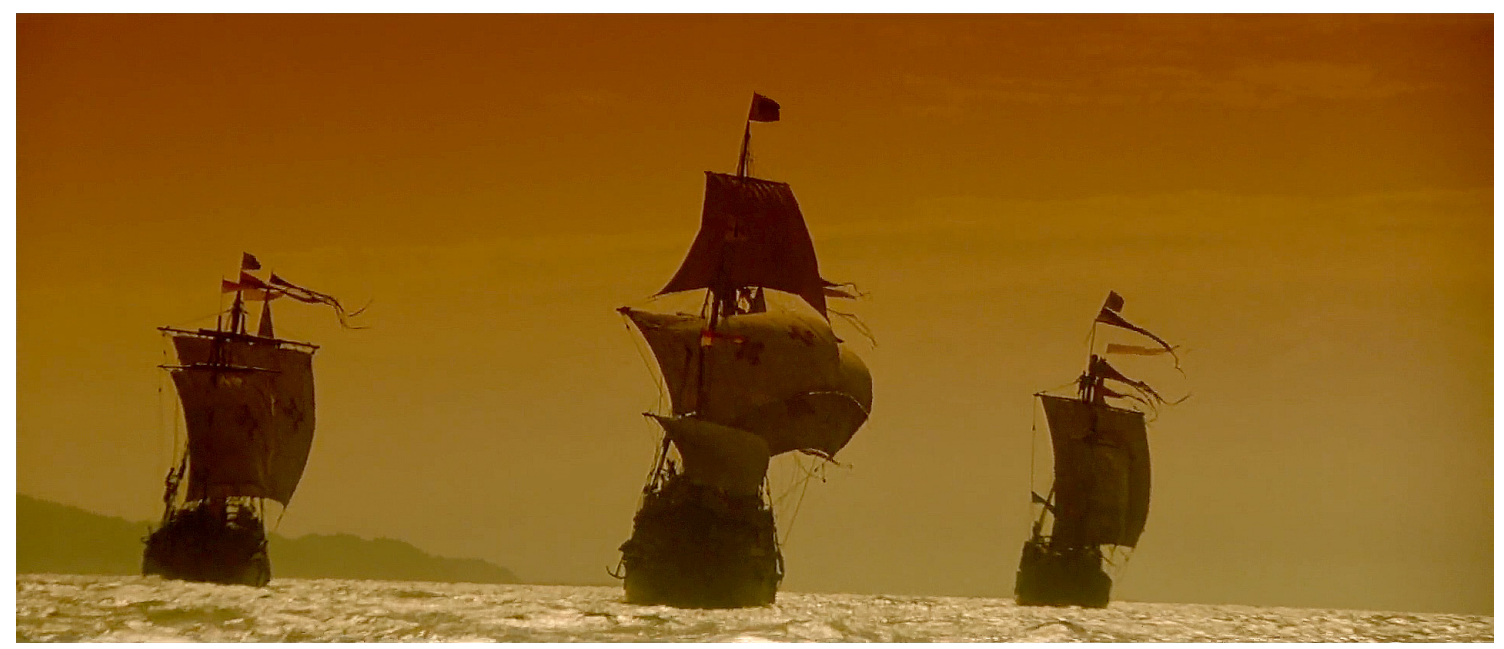

Figura 12. Fotograma de 1492. La conquista del paraíso (Scott 1992). El formato panorámico abarca enormes espacios que hacen aparecer más espectaculares los navíos. Figure 12. Frame of 1492. Conquest of Paradise (Scott 1992). Covering huge space, the panoramic format heightens the majesty of the ships.

supondría la epopeya para hacer de "España" -y por inercia, de Europa- un imperio. En este caso es Pinzón (y no los frailes, como en Alba de América) quien posibilita al marino hablar con los Reyes Católicos vía un banquero con el que tienen una deuda. Se incide, de este modo, en la importancia de la economía. En suma, la parte bélica previa brilla por su ausencia, apenas unas escenas contextuales como la reconquista de Granada, en la que "se pierde una gran cultura".

Si bien el filme de Orduña se vale de la iconografía religiosa para fortalecer la analogía heroica con la victoriosa España franquista, 1492 opta por una épica del progreso científico y geográfico europeo, por medio de espectaculares vistas marinas que sirven para engrandecer aún más la hazaña, estrategia apuntalada por la utilización del formato panorámico (2.35: 1). Mediante esta óptica se pueden abarcar grandes espacios: así, el horizonte del mar enorme, que ocupa toda la pantalla, representa la expansión del futuro Imperio español (fig. 12). En consecuencia, no es Dios, sino el ojo (la cámara) del ser humano el que expande su mirada. De idéntica forma, Scott abusa del ralentí y de una música cada vez más pronunciada y omnipresente. Siguiendo la estela de una programación narrativa clásica (la calma que precede a la tormenta), la película sigue los códigos del cine hollywoodiense, con estallidos de violenta y sangrienta acción fuera del tono pausado dominante del relato.

Como puede observarse, 1492 manifiesta una exaltación imperialista y católica de la españolidad, gran potencia colonial a modo espejo en el que mirarse desde el contexto de los años noventa, poniendo el foco en la gesta histórica y minimizando los pasajes más oscuros (que son someramente mostrados). Con la consiguiente paradoja que, dicho sea de paso, acarrea esta postura cinematográfica: el hecho de que una producción británica (país predominantemente protestante) vanaglorie lo español y, por ende, el mérito de un imperio católico. También es posible identificar un sustrato vinculado a la política europea de su época. Poco importan las disensiones cuando de la unión de contrarios surge una fuerza que beneficia políticamente a todos. En ese año se firmó el crucial Tratado de Maastricht, que consolidó la Unión Europea, en un continente acuciado por la cruenta guerra de los Balcanes, la unificación alemana y el nacimiento de nuevas naciones resultantes de la disolución soviética. En un plano cultural, el Festival de la Canción de Eurovisión premiaba el tema del artista italiano Toto Cutugno "Insieme: 1992", cuya letra proclama: "Juntos, unidos, unidos" se puede alcanzar una Europa que "no está lejos". La música compuesta por el artista griego Vangelis para la película de Scott marca la esencia europea en la nacionalidad de su autor: lo helénico como cuna de la cultura europea.

1492. La conquista del paraíso formó parte (extraoficialmente) de una sucesión de celebraciones socioculturales con motivo del v Centenario del Descubrimiento de América promovidas por la Junta de Andalucía. Es 


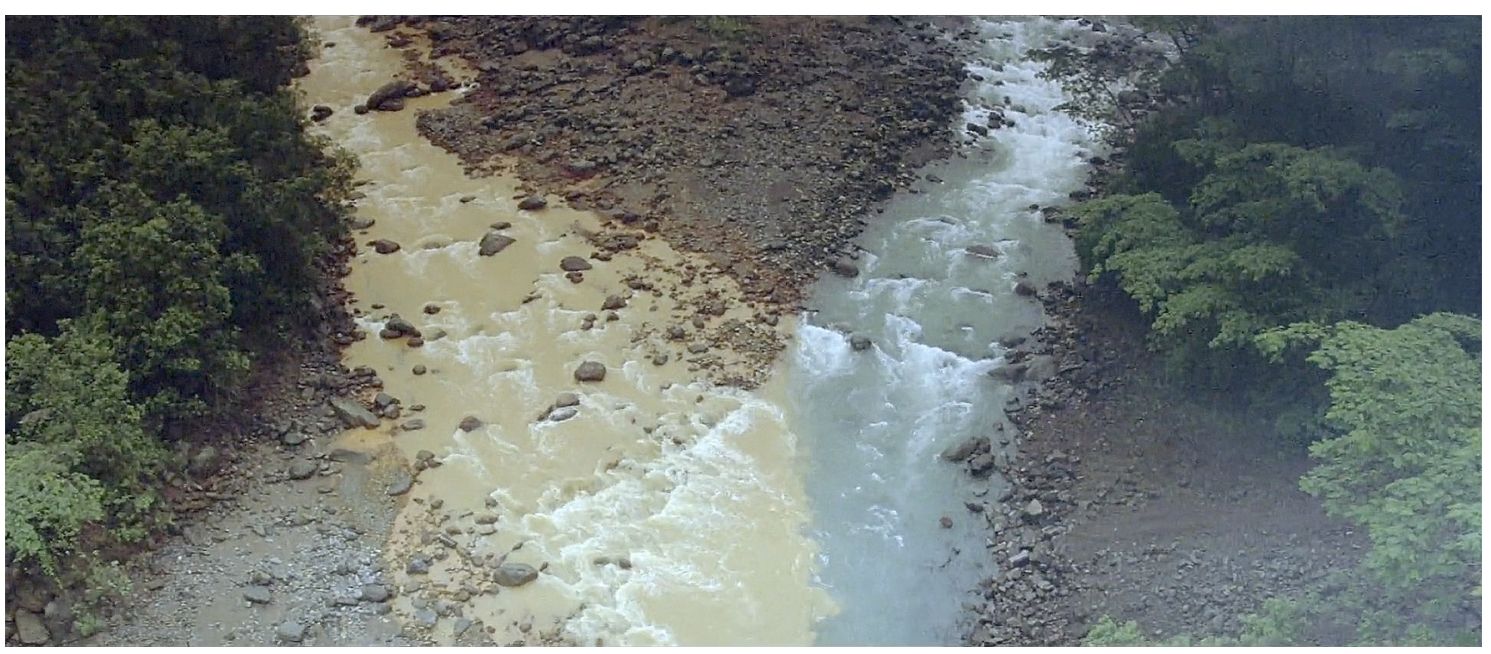

Figura 13. Fotograma de 1492. La conquista del paraíso (Scott 1992). La confluencia de la cultura europea con la americana se representa por medio de aguas turbias y limpias. Figure 13. Frame of 1492. Conquest of Paradise (Scott 1992). Convergence of the European and American cultures is represented by means of murky and clean waters.

decir: este rescate cinematográfico del marinero como ciudadano del mundo, junto con un discurso que amalgama lenguas, actores y actrices españoles con ingleses, convoca un paralelismo entre la etapa colombina y la reconquista del paraíso prometido por el proyecto europeo. Otro tanto ocurre con un injerto narrativo por el que se da a entender que los planos de las primeras construcciones domésticas del Nuevo Mundo se basaron en planos de Leonardo da Vinci -el otro gran adalid del orgullo continental-, en posesión de Colón.

En definitiva, 1492 es la historia secularizada, espectacularizada, desnacionalizada (por su naturaleza de coproducción), politizada y políglota de la gesta de la conquista. Una herramienta histórico-audiovisual empuñada en un momento significativo de la Europa posmuro de Berlín. Se consolida, por tanto, que lo que antaño fue utilizado con intereses políticos individuales y totalitarios mutó en una propuesta pacífica y unificadora. A pesar de que esa unión de corrientes -por cuyo caudal corren sujetos y objetos en continuo conflicto, tanto en el descubrimiento y la conquista de América como en la reconstrucción en Europa- sea representada en el filme con la confluencia de ríos turbios y claros (fig. 13).

\section{CONCLUSIONES}

En el caso de las obras que recrean la cultura de la Mesoamérica tardía, concluimos que tanto Mora Catlett como Gibson se valen de todos los estereotipos y arquetipos dibujados por la tradición cinematográfica en torno a la conquista de América. Ambos cineastas critican la falta de moralidad de la sociedad occidental contemporánea. Mora Catlett, desde una perspectiva político-artística ofrece una nueva manera de narrar historias, más acorde con la cultura, la materia, la forma y el tema puramente mexicano (tal como hicieran los soviéticos de los que Mora Catlett, en cierto sentido, bebe): un nuevo arte para una nueva intención narrativa. Gibson, desde una posición más global, señala la insaciabilidad del capitalismo más antiecologista. Una reflexión iusnaturalista-narrativa sobre el origen de la crueldad humana, tema inherente a los filósofos de la época que recrea su obra. Gibson cierra irónicamente la obra con las velas de los conquistadores acercándose desde el horizonte; el miedo de los nativos hace comprender que estos nuevos visitantes pondrán en jaque el anterior orden establecido.

En Alba de América se narra la (re)conquista de una España franquista, militarista y nacionalcatólica, recién vencedora en la Guerra Civil y frente al reto de convertir su territorio, a la manera del imperio de antaño, en "una, grande y libre", donde la dominación fascista de la España franquista se emparenta con el imperialismo 
de los Reyes Católicos en la época de Colón. 1492, en su celebración del europeísmo finisecular, se arroga dar el mérito a un Colón tan humano como mesiánico, de ser el primero en avistar tierra y abrir paso a un futuro prometedor para las naciones del viejo continente. Ante una Europa aún fragmentada geopolítica y económicamente, se veía necesario construir una obra que ayudase a unir simbólicamente aquellos estados disgregados hacía tan poco tiempo. En ambos filmes se constata la utilización política de un pasado falseado, en el que se simula un positivismo de personajes conscientes de la historicidad de sus hechos presentes.

A fin de cuentas, los relatos históricos y la formalización de estos discursos son "el punto de apoyo que permite, si no mover el mundo, sí hacerlo ver o crear uno nuevo al mismo tiempo" (Nadal 1986: 390). Porque América, ya sea descubierta o conquistada, fue escrita, relatada e imaginada. El cine de ficción histórico hace creer, gracias al contrato de veridicción entre el autor y el lector, que lo que cuenta sucedió así (Courtés \& Greimas 1982: 433). Aquí reside el sentido y la eficacia de estos textos audiovisuales: en configurar la esencia de lo pasado para comunicar la apariencia de lo acontecido. Las cuatro obras demuestran que el cine de ficción histórico es un mecanismo retórico, al servicio de los intereses coyunturales de una nación o varias naciones.

En resumen, estos filmes ejemplifican que el presente puede manipularse por medio de una idealización del pasado, y para ello es necesario narrar. En gran medida, debido a que "sin ideología no puede narrarse justamente, no puede construirse composición épica justa, articulada, variada" (Lukacs 1966: 203-204). O, formulado como pregunta retórica que resume esta investigación: “ipodemos alguna vez narrar sin moralizar?” (White 1992: 39).

\section{NOTAS}

${ }^{1}$ Propaganda y corriente teórico-historiográfica que, a juicio de algunos historiadores, busca omitir los logros y enfatizar la crueldad del Imperio español, la religión católica y la influencia y poder de ambos en el mundo, desde la llegada a América hasta la pérdida de la mayor parte de sus territorios de ultramar.

${ }^{2}$ Conviene señalar que Alba de América fue estrenada en el año en que se inició la construcción de la cruz del Valle de los Caídos.

\section{REFERENCIAS}

Albano, S. G. 2008. Modelos del mundo moderno: hacia un consenso de imágenes en el cine de Latinoamérica. Latinoamérica. Revista de estudios Latinoamericanos 47: 137-161.

Амıт, J. 2017. Imágenes e imaginarios sobre la conquista. Retorno a Aztlán de Juan Mora Catlett (1991): un ejercicio decolonial en el cine histórico. En Representaciones del mundo indígena en el cine hispanoamericano (documental y ficción), E. Gimeno \& K. Poe, pp. 3-23. San José: Universidad de Costa Rica.

BARTHES, R. 1970. Introducción al análisis estructural de los relatos. En Análisis estructural del relato, E. Verón, dir., pp. 9-43. Buenos Aires: Editorial Tiempo Contemporáneo.

Camarero, G. 2002. Presentación. En La mirada que habla (cine e ideologías), G. Camarero, ed., pp. 5-7. Madrid: Akal.

Casetti, F. \& F. Di Chio 1991. Cómo analizar un film. Barcelona: Paidós.

Castañeda de la Paz, M. 2005. El Códice x o los anales del grupo de la Tira de la Peregrinación. Evolución pictográfica y problemas en su análisis interpretativo. Journal de la Société des Américanistes 91 (1): 7-40.

Courtés, J. \& A. J. Greimas 1982. Semiótica. Diccionario razonado de la teoría del lenguaje. Madrid: Editorial Gredos.

Ebel, M. T. 1996. Five films of pre-Columbian culture, the discovery of the New World, and the Spanish conquest. Tesis para optar al grado de Doctor en Filosofía, Departamento de Lenguas Modernas y Lingüística, The Florida State University. <https://www.proquest.com/ docview/304232928?pq-origsite=gscholar\&fromopenvi ew=true $>$ [consultado: 15-11-2021].

EIsenstein, S. 1932. ;Que viva México! 84 min. Mexican Film Trust, EE. UU., México, URss.

EsPAÑA, R. DE. 2002. El franquismo combate la "leyenda negra”: Alba de América (1951). En La historia a través del cine. Memoria e historia en la España de la posguerra, D. Romero Campos, coord., pp. 65-91. Bilbao: Servicio Editorial UPV/EHU.

García Escudero, J. M. 1970. Vamos a hablar de cine. Barcelona: Salvat Editores.

Gibson, M. 2006. Apocalypto. 136 min. Icon Entertainment, EE. UU.

Greimas, A. J. 1973. En torno al sentido. Ensayos semióticos. Madrid: Fragua.

Huguet, M. 2002. La memoria visual de la historia reciente. En La mirada que habla (cine e ideologías), G. Camarero, ed., pp. 8-22. Madrid: Akal.

Johansson, P. K. 2016. La imagen de Aztlán en el Códice Boturini. Estudios de Cultura Náhuatl 51: 111-172.

Lacadena, A. 2007. Apocalypto y la imagen violenta de los mayas. Revista Española de Antropología Americana 37 (2): 235-250.

LÉvi-Strauss, C. 1995. Antropología estructural. Barcelona: Paidós. 
LozAnO, J. 1987. El discurso histórico. Madrid: Alianza Editorial. Lukacs, G. 1966. Problemas de realismo. Ciudad de México: Fondo de Cultura Económica.

MaCdonald, D. 1949. Christopher Columbus. 99 min. Gainsborough Pictures, Reino Unido.

Maciel, D. R., C. Iriart de Padilla \& A. Padilla 1980. Los chicanos: ensayo de introducción. En Chicanos: antología histórica y literaria, T. Villanueva \& M. de la Villa, eds., pp. 104-119. Ciudad de México: Fondo de Cultura Económica.

Méndez, M. 1974. Peregrinos de Aztlán. Barcelona: Al Alba.

Méndez Minura, M. X. 2019. Mel Gibson y su visión de América antes de la llegada de los europeos en el cine de Hollywood. En Humanidades entre pasado y futuro. Actas del I Congreso Internacional de Ciencias Humanas, s. ed., s. pp. Gral. San Martín: Escuela de Humanidades, Universidad Nacional de San Martín. <https://www. aacademica.org/maria.ximena.mendez.mihura/9.pdf $>$ [consultado: 15-11-2021].

Mignolo, W. D. 2010. Desobediencia epistémica: retórica de la modernidad, lógica de la colonialidad y gramática de la descolonialidad. Buenos Aires: Signo.

Mora Catlett, J. 1991. Retorno a Aztlán. 90 min. Cooperativa José Revueltas, México.

NADAL, J. M. 1986. La enunciación narrativa. En Investigaciones semióticas I. Actas del I Simposio Internacional de la Asociación Española de Semiótica, pp. 367-390. Madrid: Consejo Superior de Investigaciones Científicas.

NÁjera Coronado, M. I. 2019. El lenguaje ritual del fuego en los mayas del período Clásico: un acercamiento. Estudios de Cultura Maya 54: 91-127.

NAVARrete-Linares, F. 2018. Más allá de la cosmovisión y el mito. Una propuesta de renovación conceptual. Estudios de Cultura Náhuatl 56: 9-43.

ORduñA, J. DE. 1951. Alba de América. 112 min. Cifesa, España.

PÁez Lotero, C. M. 2019. Peregrinos de Aztlán: narrando los orígenes, reconociendo la nación. Philobiblion: Revista de Literaturas Hispánicas 8: 23-40.

Popper, K. R. 2014. La miseria del historicismo. Madrid: Alianza Editorial.

Pratt, M. L. 2011. Ojos imperiales. Literatura de viajes y transculturación. Buenos Aires: Fondo de Cultura Económica.

Ricoeur, P. 1997. Narratividad y fenomenología hermenéutica. En Cuaderno Gris. Época III, 2, G. Aranzueque, coord., pp. 479-495. Madrid: UAM.

Rosenstone, R. A. 1995. Visions of the past. The challenge of film to our idea of history. Cambridge, MA: Harvard University Press.

Sahagún, B. 1963 [1577]. Historia general de las cosas de Nueva España por el fray Bernardino de Sahagún: el Códice Florentino en El mito del nacimiento de Huitzilopochtli. En Una aproximación a Coyolxauhqui, Estudios de Cultura Náhuatl, J. Fernández, vol. IV, pp. 37-53. México: UNAM. $<$ https://www.inah.gob.mx/boletines/2205-el-mito-delnacimiento-de-huitzilopochtli> [consultado: 01-10-2021].
Scott, R. 1992. 1492. La conquista del paraíso. $155 \mathrm{~min}$. Paramount Pictures, Reino Unido.

Smith, R. 2002. Al este del Aztlán. La migración mexicana al este de los Estados Unidos. Revista digital Letras libres. $<$ https://www.letraslibres.com/mexico/al-este-aztlan-lamigracion-mexicana-al-este-estados-unidos $>$ [consultado: 01-10-2021].

Stoopen Galán, M. 2015. De Aztlán a México-Tenochtitlan: mitos y presagios de la peregrinación, fundación y destrucción. En Viajes y ciudades míticas, A. Baraibar \& M. Vinatea Recoba, eds., pp. 143-157 Pamplona: Servicio de Publicaciones de la Universidad de Navarra.

URIs, P. 1999. $360^{\circ}$ en torno al cine político. Badajoz: Diputación de Badajoz, Departamento de Publicaciones.

White, H. 1992. El contenido de la forma. Narrativa, discurso y representación histórica. Barcelona: Paidós.

ZunZunEGUI, S. 2016. La mirada cercana. Microanálisis fílmico. Santander: Shangrila. 